\title{
Antibody Responsiveness to Influenza: What Drives It?
}

\author{
Xia Lin ${ }^{1}$, Fangmei Lin ${ }^{1}$, Tingting Liang ${ }^{1}$, Mariette F. Ducatez ${ }^{2}$, Mark Zanin ${ }^{1,3}$ and Sook-San Wong ${ }^{1,3, *}$ \\ 1 State Key Laboratory of Respiratory Diseases, Guangzhou Medical University, 195 Dongfengxi Rd, \\ Guangzhou 510182, China; linxia618@163.com (X.L.); linfangmei@126.com (F.L.); 18671172019@163.com (T.L.); \\ mark.zanin@gird.cn (M.Z.) \\ 2 IHAP, UMR1225, Université de Toulouse, INRAe, ENVT, 31076 Toulouse, France; mariette.ducatez@envt.fr \\ 3 School of Public Health, The University of Hong Kong, Hong Kong, China \\ * Correspondence: sook-san.wong@gird.cn; Tel.: +86-178-2584-6078
}

Citation: Lin, X.; Lin, F.; Liang, T.;

Ducatez, M.F.; Zanin, M.; Wong, S.-S.

Antibody Responsiveness to

Influenza: What Drives It? Viruses

2021, 13, 1400. https://doi.org/

$10.3390 / \mathrm{v} 13071400$

Academic Editors: Sophie Valkenburg and Marios Koutsakos

Received: 30 April 2021

Accepted: 3 July 2021

Published: 19 July 2021

Publisher's Note: MDPI stays neutral with regard to jurisdictional claims in published maps and institutional affiliations.

Copyright: (C) 2021 by the authors. Licensee MDPI, Basel, Switzerland. This article is an open access article distributed under the terms and conditions of the Creative Commons Attribution (CC BY) license (https:/ / creativecommons.org/licenses/by/ $4.0 /)$.

\begin{abstract}
The induction of a specific antibody response has long been accepted as a serological hallmark of recent infection or antigen exposure. Much of our understanding of the influenza antibody response has been derived from studying antibodies that target the hemagglutinin (HA) protein. However, growing evidence points to limitations associated with this approach. In this review, we aim to highlight the issue of antibody non-responsiveness after influenza virus infection and vaccination. We will then provide an overview of the major factors known to influence antibody responsiveness to influenza after infection and vaccination. We discuss the biological factors such as age, sex, influence of prior immunity, genetics, and some chronic infections that may affect the induction of influenza antibody responses. We also discuss the technical factors, such as assay choices, strain variations, and viral properties that may influence the sensitivity of the assays used to measure influenza antibodies. Understanding these factors will hopefully provide a more comprehensive picture of what influenza immunogenicity and protection means, which will be important in our effort to improve influenza vaccines.
\end{abstract}

Keywords: influenza; antibody responses; seroconversion; immunity; vaccine

\section{Introduction \\ 1.1. Burden of Disease}

Influenza viruses cause acute respiratory infections with significant mortality and morbidity in humans [1]. Annual seasonal influenza epidemics can result in three to five million hospitalizations and 290,000 to 650,000 respiratory disease-related deaths worldwide, with younger children and the elderly disproportionately affected [2]. An estimated $20 \%$ of children are infected annually by influenza [3], while $90 \%$ of influenzaassociated deaths are due to underlying respiratory and circulatory complications in those aged 65 years or older [4]. The burden of disease is greater during pandemics involving novel subtypes for which population immunity is lacking. There have been at least four influenza pandemics in the last 100 years, the most severe of which was the 1918 pandemic that was estimated to have killed at least 50 million people [5]. Currently, two subtypes of influenza A viruses (IAVs), H1N1 and H3N2, and two lineages of influenza B viruses (IBVs), B/Yamagata and B/Victoria, are responsible for the seasonal influenza epidemics, with one or two strains dominating in a particular season or geographical location.

\subsection{Antibody Responses to Influenza Viral Proteins \\ 1.2.1. Hemagglutinin (HA) and Neuraminidase (NA)}

Hemagglutinin (HA) and neuraminidase (NA) are the two main antigenic proteins on the surface of IAVs and IBVs [6]. HA mediates binding to sialic acids on the host cells and facilitates fusion between the viral envelope and the host cell membrane [7]. A functional HA is a trimeric integral membrane protein, whose ectodomain consists of the 
globular head and the stem domain. The globular head contains the receptor binding sites and most of the human antibody responses are directed towards epitopes located here. Antibodies that target the globular head are immunodominant, affinity-matured, bind with high-specificity, and are generally neutralizing as they interfere with the binding of HA and sialic acids [8]. Due to this, the head is under the greatest immune pressure, resulting in continuous antigenic drift [9]. Immunity mediated by the HA globular headantibodies following natural infection may even provide lifelong protective immunity against antigenically-related viruses that have not undergone antigenic drift. Antibodies targeting the globular head are also the main type of antibody detected by the classical hemagglutination-inhibition (HAI) assay [8]. Although HAI-assay does not strictly measure virus neutralization activity, HAI-antibody titers are generally well-correlated with virus neutralization titers and are considered to be an established correlate of protection in healthy adults [10].

In contrast to the relatively variable HA globular head, the stem region is more conserved amongst the different subtypes. Therefore, antibodies that target the HA-stem form the majority of the broadly neutralizing influenza antibodies (bnAbs) identified so far. Whilst they are produced at very low titers after infection compared to head-antibodies [11], they have been associated with protection in human challenges [12] and animal studies [13].

NA is a sialidase expressed as a homotetrameric glycoprotein spike on the viral surface. NA is divided into four domains: the cytoplasmic tail, transmembrane domain, stem domain, and the head which contains the enzymatic active site [14]. NA cleaves the sialic acid residues on the cell surface to promote the release of the newly formed virus particles as well as their motion through the respiratory mucus [15]. Antibodies targeting NA are previously thought to be unable to inhibit virus entry, and just prevent viral egress [11], but a recent study showed otherwise [16]. The contribution of NA-specific antibodies in reducing disease severity was recognized nearly fifty years ago during the 1968 A(H3N2) pandemic [17]. Epidemiological studies since then have shown that independent of HA, NA antibodies are also a predictor of immunity to influenza virus infections as they can limit or even prevent disease [18-22]. There is also evidence that NA vaccination prevents virus transmission in the guinea pig model [23]. Notably, the antigenic evolution of NA is slower than HA, thus antibodies targeting NA can potentially provide longer-term immunity compared to HA-antibodies [24]. In addition, NA-antibodies usually show broad cross-reactivity, and monoclonal antibodies that cross-react with NAs across influenza subtypes and even types have recently been identified $[9,25]$. Although currently licensed inactivated influenza vaccines generally contain sufficient residual amounts of NA to induce NA-antibodies [26], this response has not been systematically studied as the NA-content and tetrameric NA activity in vaccines are not standardized [27].

\subsubsection{Matrix 2 (M2) and Nucleoprotein (NP)}

Another protein on the virus surface is the Matrix 2 (M2) protein, which is present at lower molar amounts compared to HA and NA but is expressed in large quantities on the surface of infected cells [28]. M2 is a tetrameric transmembrane protein that functions as a proton-channel and, whilst it is highly conserved across influenza subtypes, it is poorly immunogenic due to its low abundance and inaccessibility to antibodies $[29,30]$. However, its conservation makes it a promising target and, as such, the M2-ectodomain (M2e), has been developed as a subunit vaccine candidate [31]. In mice, M2e antibodies were shown to be protective, although the mechanism of protection appeared to be Fcmediated [32,33]. Another conserved viral protein with reported protective function is the Nucleoprotein (NP), which is located within the viral envelope. Although NP has an important role in $\mathrm{CD}^{+} \mathrm{T}$-cell mediated protection, antibodies targeting NP have been reported to provide some heterosubtypic protection in mice studies through nonneutralizing immune mechanisms [34]. The remaining viral proteins are internal and elicit relatively fewer antibodies with unknown significance for protection. 


\section{Immune Mechanisms of Protection}

\subsection{Virus Neutralization}

The classical and most established correlate of protection against influenza virus infection is the presence of HAI-antibodies. Because HAI-antibodies recognize proteins on the virus surface and are generally well correlated with neutralization activity, its mechanism of action is postulated to be via direct binding and clearance of virus particles in the infected hosts. Based on the study conducted by Dobson et al., an HAI titer $\geq 1: 40$ was associated with a 50\% reduction in infection risks in a healthy adult population [35]. This standard, considered to be the "seroprotective" threshold, has been adopted by both the U.S. Food and Drug Administration and the European Medicines Agency's Committee on Human Use of Medicines for Influenza Vaccine Licensure. However, this seroprotective titer may not apply to young children or the elderly, since their immunological status likely differs compared to healthy adults [36,37].

Aside from the HA globular head, antibodies targeting other viral epitopes can also inhibit influenza virus infections in vitro and show protection in animal models. As described above, broadly-neutralizing influenza antibodies typically target conserved HA and NA epitopes, although may not be elicited in high titers after infection [38]. Dugan et al., recently showed that monoclonal antibodies targeting NA but not NP had neutralization activity and were protective in virus-challenged mice. However, their neutralization and protective potency were reduced compared to HA-globular head or HA-stem antibodies [16].

\subsection{Fc-Mediated Mechanisms}

The application of novel immunological approaches has identified a role for influenza antibodies in mechanisms of immune protection, other than virus neutralization. Nonneutralizing influenza antibodies can also mediate clearance of infected cells through Fc-dependent mechanisms namely, antibody-dependent cellular toxicity (ADCC), antibodydependent cellular phagocytosis (ADCP), and complement-dependent cellular toxicity (CDCC) [39,40]. ADCC is primarily mediated through human Fc $\gamma$ RIIIa found on natural killer (NK) cells, monocytes, and macrophages that release cytolytic enzymes when they recognize an IgG-bound immune complex on the surface of infected cells [41,42]. Aside from homologous strain reactivity, cross-reactive influenza ADCC antibodies can be detected in the sera of healthy individuals, individuals previously infected with the 2009 A(H1N1) pandemic strains, or those vaccinated with seasonal inactivated influenza vaccines $[43,44]$. Vaccination with $2014-15$ seasonal influenza vaccine can induce HAspecific non-neutralizing antibodies, with strong ADCC activity even against antigenically drifted A(H3N2) viruses [44]. Seasonal vaccination of the elderly can also induce antibodies with strong ADCC activity, including against $\mathrm{H} 5$ and $\mathrm{H} 7$ subtypes [45]. Antibodies with ADCC activity that recognize internal viral proteins such as NP, M, and M2 have also been detected after influenza infection and vaccination [8], some of which have been shown to be protective in mouse studies [46].

ADCP is the antibody-mediated opsonization of infected cells expressing viral antigens on their surface by effector cells such as macrophages and neutrophils [47,48]. Antibodies with ADCP activity detected in post-infection human and macaque sera have been associated with reduction of infectivity in vitro and can be cross-reactive [49].

In CDCC, the complement proteins, which are soluble or membrane-bound factors that circulate in the blood and tissues, contribute to protection via direct clearance of pathogens or enhancement of adaptive immune responses. Influenza viruses can be neutralized via all three complement pathways, classical, alternative, or the mannose-binding lectin (MBL) pathway [50,51]. Although non-antigen-specific IgM (natural antibodies) can induce CDCC-mediated neutralization of influenza viruses [51], maximum benefits appeared to be elicited through antigen-specific antibody-mediated activation of both classical and alternative pathways [52]. As in ADCC, non-neutralizing ADPC and CDCC antibodies typically target non-HA1 epitopes and conserved proteins such as M2 [53-56]. These 
antibodies can mediate viral clearance either exclusively or through multiple Fc-mediated mechanisms [54,57].

In summary, non-neutralizing antibodies can be detected in the population, seemingly accumulate with age, and may contribute to protection against newly emerging influenza viruses, although the degree of in vivo protection in humans has not yet been formally established.

\subsection{T-Cell Mediated Immunity}

Cell-mediated immunity has also been shown to be a correlate of protection against influenza, particularly in reducing disease severity. T-cell mediated immunity mainly targets the more conserved internal viral proteins, such as NP, matrix protein 1 (M1), or the polymerase proteins (PA, PB1, PB2) [8], and as such, can potentially provide broader protection against different strains and subtypes. Both preexisting $\mathrm{CD} 8^{+}$and $\mathrm{CD} 4^{+} \mathrm{T}$ cells have been associated with reduced symptoms and viral shedding after infection in humans [58,59] and in a non-human primate challenge study [60].

At present, HAI-antibodies are best associated with protection from influenza virus infection and disease. However, as shown from human and animal studies [12,21], other non-HAI responses may also represent significant immune correlates of protection. These potential correlates are understudied, primarily due to the lack of standardized assays.

\section{Signatures of Robust Antibody Response}

\subsection{Genetic Correlates of Antibody Response}

Systems biology studies profiling human vaccine-induced transcriptomics responses have identified genes that predicted the immune response of a vaccine against the yellow fever virus [61,62]. Since then, transcriptomic profiling of the immune response to influenza virus infection and vaccination has contributed to our understanding of factors influencing robust antibody response [63]. Most of these studies were conducted using peripheral blood, which is easier to sample.

The strongest predictor of robust antibody response after influenza vaccination is the upregulation of the interferon (IFN) signaling genes (ISG), regardless of age or vaccines [64-68]. Strong induction of IFN gene expression positively correlated with the magnitude of the vaccine-induced antibody response to both live-attenuated influenza vaccine (LAIV) and trivalent inactivated influenza vaccine (TIV). Although a more rapid IFN-response in the peripheral blood was reported for TIV, it is unclear how much of this was influenced the route of vaccine administration [67]. Furthermore, the addition of squalene oil-in-water adjuvants to TIV also showed the same correlation between IFN-signature and the magnitude of HAI-titers in children and adults [68].

In addition to IFN-gene expression, genes that regulate B-cell proliferation have also been associated with a robust antibody response [69]. Among the differentially expressed genes induced after influenza vaccination, most are highly expressed in antibodysecreting cells [65] and dendritic cells [65,68]. Other markers of vaccine response included activation of genes associated with apoptosis function [70], membrane trafficking, and antigen processing [71].

Gene expression analysis in post-infection peripheral blood in a cohort of IAV-infected participants within $48 \mathrm{~h}$ of illness onset identified a total of 229 genes that correlated with development of HAI-titers. Similar to post-vaccination responses, most of the positively correlated genes were immune-related and associated with B-cell proliferation, while most of the negatively correlated genes were involved in programmed cell death pathways [72], likely due to the activation and proliferation of immune cells.

\subsection{Cellular Correlates of Antibody Response}

The production of high-affinity, durable antibody and B-cell memory responses, which require the initiation of a germinal center (GC) response in secondary lymphoid organs, is a multi-step process involving multiple innate and adaptive immune cells and cytokine 
signals. On a cellular level, studies have shown that early proliferation of plasmablasts or antibody-secreting cells (ASC) are a marker of subsequent antibody rise after vaccination [73]. Recent studies have also identified the circulating counterpart of the CD4 ${ }^{+}$ T-follicular helper cells (cTfh) as a marker of antibody responsiveness after influenza virus vaccination [74]. Identifying early cellular correlates of antibody production after infection is more challenging due to the difficulties in obtaining early blood samples, although we recently identified actively proliferating $\mathrm{CD} 4^{+} \mathrm{T}$-cells as a cellular correlate of subsequent seroconversion [75]. Activated cTfh-1 has also been found to be a predictor of robust antibody response in SARS-CoV-2 infections [76,77].

In summary, host signatures associated with robust antibody response are largely conserved at a global level in the peripheral blood between influenza vaccination and infection in that they stimulate a strong IFN-driven pro-inflammatory response, initiate antigen presentation, and activation of $\mathrm{CD} 4^{+} \mathrm{T}$-cells and B-cells early in the course of exposure. A summary of representative studies and their key findings are shown in Table 1.

Table 1. Representative studies on the genetic and cellular correlates of robust antibody responses after influenza vaccination or infection.

\begin{tabular}{|c|c|c|c|c|c|c|c|}
\hline & & Cohort & $\begin{array}{l}\text { Formula- } \\
\text { tion/Strain }\end{array}$ & Season & Study Design & Findings & Reference \\
\hline \multirow{8}{*}{ 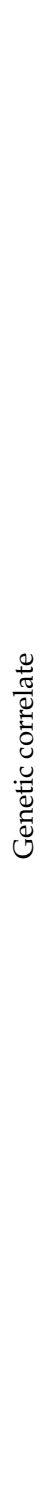 } & \multirow{8}{*}{ 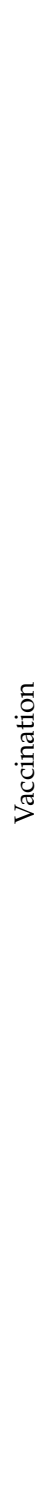 } & $\begin{array}{l}\text { Children aged } \\
\text { 12-35 months, } \\
\quad N=85\end{array}$ & LAIV and TIV & 2006-2007 & $\begin{array}{c}\text { Transcriptional profiling by } \\
\text { microarray of whole blood } \\
\text { RNA at Day } 7 \\
\text { post-vaccination. }\end{array}$ & $\begin{array}{l}\text { Type } 1 \text { interferon-stimulated } \\
\text { gene (ISG) was upregulated, } \\
\text { particularly robust in LAIV } \\
\text { recipients although no } \\
\text { correlation to antibody data } \\
\text { was available. }\end{array}$ & [78] \\
\hline & & $\begin{array}{l}\text { Children aged } \\
6 \text { months to } 14 \\
\text { years, } N=37\end{array}$ & LAIV and TIV & 2010-2011 & $\begin{array}{c}\text { Blood samples were collected } \\
\text { on day } 0 \text { before vaccination } \\
\text { and on days } 1,7 \text {, and } 30 \text { after } \\
\text { vaccination to measure gene } \\
\text { expression profiles. }\end{array}$ & $\begin{array}{l}\text { TIV had a more rapid } \\
\text { IFN-response compared to } \\
\text { LAIV. The overexpression of } \\
\text { IFN genes in TIV and LAIV } \\
\text { was correlated with H3N2 } \\
\text { antibody titers. }\end{array}$ & [67] \\
\hline & & $\begin{array}{l}\text { Children aged } \\
\text { 14-24 months, } \\
\quad N=90\end{array}$ & $\begin{array}{c}\text { TIV and } \\
\text { adjuvanted TIV }\end{array}$ & 2012-2013 & $\begin{array}{l}\text { Transcriptional profiling by } \\
\text { microarray of whole blood } \\
\text { RNA at Day } 1,3,7 \text {, and } 28 \\
\text { post-vaccination. }\end{array}$ & $\begin{array}{l}\text { TIV with adjuvant showed } \\
\text { gene differences in IFN genes, } \\
\text { dendritic, and monocyte cells, } \\
\text { which was correlated with the } \\
\text { antibody response. }\end{array}$ & [68] \\
\hline & & $\begin{array}{l}\text { Adults, males } \\
\text { aged } 18-40 \\
\text { years, } N=119\end{array}$ & TIV & 2008-2009 & $\begin{array}{l}\text { Microarray analysis of } \\
\text { peripheral blood samples } \\
\text { before and on days } 1,3 \text {, and } \\
14 \text { post-vaccination. }\end{array}$ & $\begin{array}{l}\text { Upregulation of IFN genes } \\
\text { and antigen presentation } \\
\text { pathways was associated } \\
\text { with higher vaccine-induced } \\
\text { antibody response. }\end{array}$ & {$[64]$} \\
\hline & & $\begin{array}{l}\text { Adults aged } \\
\text { 18-50 years, } \\
\quad N=67\end{array}$ & LAIV and TIV & 2008-2010 & $\begin{array}{l}\text { Microarray analyses of the } \\
\text { gene expression profiles of } \\
\text { PBMC at baseline, and days } 3 \\
\text { and } 7 \text { post-vaccination. }\end{array}$ & $\begin{array}{l}\text { Molecular signatures can be } \\
\text { used to predict later antibody } \\
\text { responses. Most of the genes } \\
\text { induced by influenza } \\
\text { vaccination are highly } \\
\text { expressed in } \\
\text { antibody-secreting cells. }\end{array}$ & [65] \\
\hline & & $\begin{array}{l}\text { Adults aged } \\
18-40 \text { years, } \\
\quad N=119\end{array}$ & TIV & $2008-2009$ & $\begin{array}{l}\text { Global transcript abundance } \\
\text { analysis of peripheral blood } \\
\text { RNA specimens before and at } \\
\text { days } 1,3 \text {, and } 14 \\
\text { post-vaccination. }\end{array}$ & $\begin{array}{l}\text { Membrane trafficking and } \\
\text { antigen processing were } \\
\text { associated with the immune } \\
\text { response to the vaccine. }\end{array}$ & {$[71]$} \\
\hline & & $\begin{array}{l}\text { Adults aged } \\
18-45 \text { years, } \\
\quad N=60\end{array}$ & TIV & 2012-2013 & $\begin{array}{l}\text { Transcriptomic analysis of } \\
\text { blood samples at days } 0,1, \\
\text { and } 21 \text { post-vaccination. }\end{array}$ & $\begin{array}{l}\text { Serum levels of CXCL10 were } \\
\text { correlated with T cell and } \\
\text { antibody responses after } \\
\text { vaccination. }\end{array}$ & [79] \\
\hline & & $\begin{array}{c}\text { Adults and } \\
\text { elderly aged } 20 \\
\text { to }>89 \text { years, } \\
N=91\end{array}$ & TIV & 2008-2009 & $\begin{array}{c}\text { Whole-blood microarray } \\
\text { analysis of gene expression at } \\
\text { days } 0 \text { and } 28 \pm 7 \\
\text { post-vaccination }\end{array}$ & $\begin{array}{l}\text { Genes involved in apoptosis } \\
\text { were positively associated } \\
\text { with vaccine-induced } \\
\text { antibody response. }\end{array}$ & [70] \\
\hline
\end{tabular}


Table 1. Cont.

\begin{tabular}{|c|c|c|c|c|c|c|c|}
\hline & & Cohort & $\begin{array}{l}\text { Formula- } \\
\text { tion/Strain }\end{array}$ & Season & Study Design & Findings & Reference \\
\hline & 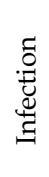 & $\begin{array}{l}\text { Adults aged } \\
18-49 \text { years, } \\
\quad N=58\end{array}$ & $\begin{array}{l}\text { Influenza A and } \\
\text { influenza B }\end{array}$ & 2009-2011 & $\begin{array}{l}\text { Peripheral blood gene } \\
\text { expression profiling at Day 0, } \\
2,4,6 \text {, and } 21 \text { post-infection. }\end{array}$ & $\begin{array}{l}\text { Influenza virus infection } \\
\text { caused greater magnitude } \\
\text { and longer duration of } \\
\text { upregulation of interferon } \\
\text { signaling pathway genes. }\end{array}$ & [72] \\
\hline \multirow{5}{*}{ 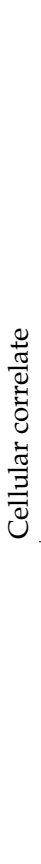 } & \multirow{3}{*}{ 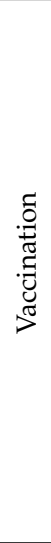 } & $\begin{array}{l}\text { Adults aged } \\
\geq 18 \text { years, } \\
\quad N=44\end{array}$ & $\begin{array}{l}\text { MF59- } \\
\text { adjuvanted } \\
\text { H5N1 }\end{array}$ & $\begin{array}{l}\text { A/Vietnam/119 } \\
\text { (H5N1), given } \\
\text { as part of a } \\
\text { trial with } \\
\text { 3-study arms }\end{array}$ & $\begin{array}{l}2004 \\
\text { PBMC was collected at } \\
\text { baseline and } 3 \text { weeks } \\
\text { post-vaccination. }\end{array}$ & $\begin{array}{c}\text { Expansion of ICOS + IL-21 + } \\
\text { CD4 }{ }^{+} \mathrm{T} \text { cells was an early } \\
\text { marker of antibody response. }\end{array}$ & [80] \\
\hline & & $\begin{array}{l}\text { Adults, } N=49 \\
\text { and children, } \\
\qquad N=20\end{array}$ & TIV & 2009-2012 & $\begin{array}{l}\text { PBMC was collected at } \\
\text { baseline and day } 7 \\
\text { post-vaccination }\end{array}$ & $\begin{array}{l}\text { ICOS + CXCR3 + CXCR5 + } \\
\text { CD } 4^{+} \text {T cells correlated with } \\
\text { antibody response induced } \\
\text { by memory B cells. }\end{array}$ & [81] \\
\hline & & $\begin{array}{c}\text { Adults aged } \\
30-40 \text { years, } N \\
=28 \text { and } \\
\text { elderly aged } \\
\geq 65 \text { years, } \\
N=35\end{array}$ & TIV & 2012-2013 & $\begin{array}{l}\text { PBMC was collected on days } \\
0,7 \text {, and } 14 \text { post-vaccination. }\end{array}$ & $\begin{array}{l}\text { Circulating Tfh cells } \\
\text { predicted antibody response } \\
\text { in young but not elderly. }\end{array}$ & [82] \\
\hline & 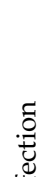 & $\begin{array}{l}\text { Children and } \\
\text { adults, aged } \\
0-90 \text { years, } \\
N=16\end{array}$ & $\begin{array}{l}\text { Influenza A and } \\
\text { influenza B }\end{array}$ & $\begin{array}{l}\text { 2013-2015 in } \\
\text { New Zealand }\end{array}$ & $\begin{array}{c}\text { PBMC collected immediately } \\
\text { and at least } 14 \text { days after } \\
\text { enrollment }\end{array}$ & $\begin{array}{c}\mathrm{CD}^{+} \mathrm{T} \text {-cells proliferation } \\
\text { and greater inflammatory } \\
\text { monocytes depletion was } \\
\text { associated with } \\
\text { HAI-seroconversion }\end{array}$ & [75] \\
\hline & $\Xi$ & $\begin{array}{l}\text { Children, aged } \\
2 \text { months to } 34 \\
\text { years, } N=19\end{array}$ & $\begin{array}{l}\text { Influenza A and } \\
\text { influenza B }\end{array}$ & $\begin{array}{l}\text { 2009-2013 in } \\
\text { Memphis, TN }\end{array}$ & $\begin{array}{l}\text { Nasal washes collected } \\
\text { longitudinally upon } \\
\text { enrollment }\end{array}$ & $\begin{array}{l}\text { Inflammatory monocytes } \\
\text { depletion was associated with } \\
\text { subsequent production of } \\
\text { nasal mucosal IgA and IgG }\end{array}$ & \\
\hline
\end{tabular}

\section{Antibody Non-Responsiveness after Vaccination}

Although there are many licensed formulations for seasonal influenza vaccines, the two most established are the Inactivated Influenza Vaccine (IIV) and LAIV, which contain either three (trivalent, TIV) or four (quadrivalent, QIV) strains and are updated annually for the Northern or Southern Hemisphere based on the strains most likely to predominate in the upcoming influenza season. TIV and QIV contain two subtypes of IAV, A(H1N1) and A(H3N2), TIV contains one IBV, which was predicted to be the dominant circulating lineage for that year, while QIV will contain IBVs from both lineages (Yamagata and Victoria). LAIV is based on an "attenuated", cold-adapted virus strain expressing the HA and NA of the recommended vaccine strains. LAIV replicates optimally at $25^{\circ} \mathrm{C}$, and not at temperatures higher than $35^{\circ} \mathrm{C}$, which is the temperature of the respiratory tract. This limited replication capacity of LAIV can stimulate both local humoral and cell-mediated immunity, unlike IIVs which do not induce a robust cell-mediated response. The immunogenicity of a vaccine is typically based on seroconversion rates or the development of seroprotective titers (HAI titer $\geq 1: 40)$ [83].

Influenza vaccine immunogenicity is well-studied and many reviews and metaanalyses are available that summarize these findings. Not surprisingly, immunogenicity is dependent on age, disease, immune status, and pre-existing influenza immunity, which will be discussed in further detail below.

On the vaccine side, vaccine manufacturing processes, batch-to-batch variation, and vaccine virus strains can impact immunogenicity [84]. For example, a review of the seroconversion rates elicited by vaccines against A/Viet Nam/1203/2004 (H5N1) in vaccine trials showed that vaccines with equivalent amounts of HA but from different manufacturers elicited seroconversion rates ranging from $0 \%$ to $43 \%$ [85]. In addition, vaccines against avian influenza strains are notoriously poorly immunogenic in humans [85], requiring 
higher doses or adjuvants to induce acceptable seroconversion rates [86,87]. Amongst the different avian influenza vaccines that proceeded to Phase II trials, those against A(H7N9) viruses performed the best $[88,89]$, although not to the level seen with seasonal influenza vaccines. This is not due to the inherently poor immunogenicity of avian strains, as A(H7N9) and TIV induced comparable titers in naïve ferrets, suggesting that insufficient immune priming might be a factor for the poor responses seen in humans. We and others have reported that physical composition and protein integrity may play a role in the antibody response against a vaccine $[85,90]$.

Another significant example of the impact of influenza strain on vaccine immunogenicity is the poor performance of the A(H1N1) component of LAIV, which was the 2009 A(H1N1) pandemic virus [91]. Between 2010 to 2016, the US CDC vaccine efficacy (VE) studies reported poor VE against A(H1N1) provided by LAIV. Since its introduction into LAIV, the $2009 \mathrm{~A}(\mathrm{H} 1 \mathrm{~N} 1)$ pandemic component did not appear to replicate nor induce any HAI-antibodies, unlike the $\mathrm{A}(\mathrm{H} 3 \mathrm{~N} 2)$ or IBV components of the vaccine [92]. Many potential factors have been ascribed to this observed decreased effectiveness, including the poor replicative fitness and thermal stability of the early vaccine strain. A change to a strain with higher replicative ability based on in vitro assays for the 2017/2018 influenza season resulted in improved immunogenicity, shedding, and VE in the UK where it was recommended for use $[93,94]$.

\section{Antibody Non-Responsiveness after Infection}

Identifying the correlates of a robust antibody response is easier within the context of vaccination due to a temporally defined pre and post-antigen exposure that facilitates sample and data collection. In the case of influenza, seroconversion would typically be based on HAI-antibody titer increases, which was the cornerstone of influenza diagnosis before the advent of molecular techniques. However, the use of both PCR-diagnosis and serology in large seroepidemiological and human challenge studies has indicated that influenza virus infections do not always result in seroconversions (Table 2).

Early LAIV trials and recent human challenge studies have been useful in delineating the association between pre-existing immunity and infection doses with subsequent antibody responses. In general, a larger infection dose is associated with a higher seroconversion rate and higher antibody titers $[59,95,96]$, although this relationship is not linear past a specific threshold dose. Memoli et al. showed that an infectious dose greater than $10^{6}$ tissue-culture infectious dose-50 (TCID50) of the H1N1pdm09 strain induced seroconversion in $85 \%$ of volunteers, while lower doses induced seroconversion in only $20 \%$ of volunteers. Notably, a similar study using an A(H3N2) virus found seroconversion in only $29 \%(10 / 35)$ of inoculated volunteers. It is also worth noting that the cohort had high serum N2-antibody titers, which could have been a contributing factor in the less efficient challenge compared to the H1N1pdm09 challenge study [97]. Studies using LAIV, in which shedding of vaccine virus is a measure of successful infection, have shown that preexisting immunity, including mucosal antibodies, can prevent viral shedding. Although non-shedding does not preclude induction of systemic HAI-antibodies, positive shedders tended to have a larger fold increase in the subsequent antibody response $[98,99]$, which was in line with animal studies [100].

How does this translate to the community setting? Prior to the emergence of coronavirus disease 2019 (COVID-19), relatively few community surveillance studies that combine serologic with a molecular diagnosis were conducted. A seroepidemiologic study conducted in Singapore during the 2009 A(H1N1) pandemic reported that $80 \%$ of laboratory-confirmed individuals eventually seroconverted [101], while we observed only $32 \%$ of seroconversion in a New Zealand cohort during an A(H3N2) and IBV-dominated season [75]. In the latter study, seroconversion was more frequently observed in hospitalized patients, consistent with data from human challenge and COVID-19 studies [102] that suggest that severity of infection may correlate with the induction of antibody responses [95]. A recent multicenter study on the burden of respiratory infections in infants 
showed that $23 \%$ of influenza-positive infants did not seroconvert to the tested strains by HAI or microneutralization assays [103].

Table 2. Seroconversion events reported in human influenza challenge studies, representative trials with live-attenuated influenza vaccines (LAIV), and seroepidemiologic studies.

\begin{tabular}{|c|c|c|c|c|c|c|}
\hline $\begin{array}{l}\text { Type of } \\
\text { Study }\end{array}$ & Study & Study Design & Subtype & $\begin{array}{c}\text { No. } \\
\text { Infected }\end{array}$ & $\begin{array}{l}\text { No. Serocon- } \\
\text { version }(\%)\end{array}$ & References \\
\hline $\begin{array}{l}\text { Human } \\
\text { Challenge }\end{array}$ & $\begin{array}{l}\text { Validation of the wild-type influenza A } \\
\text { human challenge model H1N1pdMIST: } \\
\text { An A(H1N1) pdm09 dose-finding } \\
\text { investigational new drug study }\end{array}$ & $10^{3}$ to $10^{7}$ TCID $_{50}{ }^{\text {a }}$ & $\begin{array}{l}\text { A/Califor- } \\
\text { nia/04/2009 } \\
\text { (H1N1) }\end{array}$ & 46 & $29 / 46(63 \%)$ & [95] \\
\hline $\begin{array}{l}\text { Human } \\
\text { Challenge }\end{array}$ & $\begin{array}{l}\text { A Dose-finding Study of a Wild-type } \\
\text { Influenza A(H3N2) Virus in a Healthy } \\
\text { Volunteer Human Challenge Model }\end{array}$ & $10^{4}$ to $10^{7} \mathrm{TCID}_{50}$ & $\begin{array}{l}\text { A/Bethes- } \\
\text { da/MM1/2011 } \\
\text { (H3N2) }\end{array}$ & 37 & $10 / 35^{b}(29 \%)$ & [97] \\
\hline $\begin{array}{l}\text { Human } \\
\text { Challenge }\end{array}$ & $\begin{array}{c}\text { Characterization of a wild-type } \\
\text { influenza }(\mathrm{A} / \mathrm{H} 1 \mathrm{~N} 1) \text { virus strain as an } \\
\text { experimental challenge agent } \\
\text { in humans }\end{array}$ & $10^{4}$ to $10^{6} \mathrm{TCID}_{50}$ & $\begin{array}{l}\text { A/Califor- } \\
\text { nia/04/2009 } \\
\text { (H1N1) }\end{array}$ & 29 & $14 / 29(28 \%)$ & [96] \\
\hline \multirow{2}{*}{$\begin{array}{l}\text { Human } \\
\text { Challenge }\end{array}$} & \multirow{2}{*}{$\begin{array}{l}\text { Preexisting influenza-specific } \mathrm{CD}^{+} \mathrm{T} \\
\text { cells correlate with disease protection } \\
\text { against influenza challenge in humans }\end{array}$} & \multirow{2}{*}{$10^{3}$ to $10^{6} \mathrm{TCID}_{50}$} & $\begin{array}{l}\text { A/Wiscon- } \\
\text { sin/67/2005 } \\
\text { (H3N2, cell } \\
\text { grown) }\end{array}$ & 17 & $7 / 14^{\mathrm{b}}(50 \%)$ & \multirow{2}{*}{ [59] } \\
\hline & & & $\begin{array}{c}\text { A/Bris- } \\
\text { bane } / 59 / 2007 \\
\text { (H1N1, egg } \\
\text { grown) }\end{array}$ & 24 & $9 / 24(38 \%)$ & \\
\hline $\begin{array}{l}\text { Human } \\
\text { Challenge }\end{array}$ & $\begin{array}{l}\text { Landscape of coordinated immune } \\
\text { responses to H1N1 challenge } \\
\text { in humans }\end{array}$ & $\begin{array}{c}3.5 \times 10^{6} \text { to } 7 \times \\
10^{6} \mathrm{TCID}_{50}\end{array}$ & $\begin{array}{l}\text { A/Califor- } \\
\text { nia/04/2009 } \\
\text { (H1N1) }\end{array}$ & 35 & $20 / 35(57 \%)$ & [104] \\
\hline \multirow[b]{2}{*}{ LAIV trial } & \multirow{2}{*}{$\begin{array}{c}\text { Evaluation of A/Alaska/6/77 (H3N2) } \\
\text { cold-adapted recombinant viruses } \\
\text { derived from A/Ann Arbor /6/60 } \\
\text { cold-adapted donor virus in adult } \\
\text { seronegative volunteers }\end{array}$} & $1.5 \times 10^{4} \mathrm{TCID}_{50}$ & $\begin{array}{c}\text { A/Alaska/6/1977 } \\
\text { (H3N2, } \\
\text { wild-type) }\end{array}$ & 8 & $7 / 8(75 \%)$ & \multirow[b]{2}{*}{ [105] } \\
\hline & & $\begin{array}{c}3.2 \times 10^{7} \text { to } 5 \times \\
10^{7} \mathrm{TCID}_{50}\end{array}$ & $\begin{array}{c}\text { A/Alaska/6/1977 } \\
\text { (H3N2, } \\
\text { cold-adapted } \\
\text { clones) }\end{array}$ & & & \\
\hline \multirow[b]{2}{*}{ LAIV trial } & \multirow{2}{*}{$\begin{array}{c}\text { Dose-response of A/Alaska /6/77 } \\
\text { (H3N2) cold-adapted reassortant } \\
\text { vaccine virus in adult volunteers: role } \\
\text { of local antibody in resistance to } \\
\text { infection with vaccine virus. }\end{array}$} & $1.5 \times 10^{4} \mathrm{TCID}_{50}$ & $\begin{array}{c}\text { A/Alaska/6/1977 } \\
\text { (H3N2, } \\
\text { wild-type) }\end{array}$ & 8 & $7 / 8(75 \%)$ & \multirow[b]{2}{*}{ [98] } \\
\hline & & $\begin{array}{l}3.2 \times 10^{7} \\
3.2 \times 10^{6} \\
3.2 \times 10^{5} \\
3.2 \times 10^{4}\end{array}$ & $\begin{array}{c}\text { A/Alaska/6/1977 } \\
(\mathrm{H} 3 \mathrm{~N} 2, \\
\text { cold-adapted } \\
\text { clone, CR29) }\end{array}$ & $\begin{array}{l}24 \\
15 \\
15 \\
12\end{array}$ & $\begin{array}{c}50 \% \\
40 \% \\
20 \% \\
8 \%\end{array}$ & \\
\hline $\begin{array}{l}\text { Seroepide- } \\
\text { miologic }\end{array}$ & $\begin{array}{l}2009 \text { influenza } \mathrm{A}(\mathrm{H} 1 \mathrm{~N} 1) \\
\text { seroconversion rates and risk factors } \\
\text { among distinct adult cohorts in } \\
\text { Singapore }\end{array}$ & $\begin{array}{l}\text { Observational } \\
\text { Cohort }\end{array}$ & $\begin{array}{c}\text { A/California/04/2009 } \\
\text { (H1N1) }\end{array}$ & 56 & $45(80 \%)$ & [101] \\
\hline $\begin{array}{l}\text { Seroepide- } \\
\text { miologic }\end{array}$ & $\begin{array}{c}\text { Activated CD } 4^{+} \text {T-cells and } \mathrm{CD} 14^{++} \\
\mathrm{CD} 16^{+} \text {monocytes correlate with } \\
\text { antibody response following influenza } \\
\text { virus infection in humans }\end{array}$ & $\begin{array}{l}\text { Observational } \\
\text { Cohort }\end{array}$ & Influenza A and B & 66 & $21(32 \%)$ & {$[75]$} \\
\hline $\begin{array}{l}\text { Seroepide- } \\
\text { miologic }\end{array}$ & $\begin{array}{l}\text { Underdetection of } \\
\text { laboratory-confirmed } \\
\text { influenza-associated hospital } \\
\text { admissions among infants: a } \\
\text { multicentre, prospective study }\end{array}$ & $\begin{array}{l}\text { Observational } \\
\text { Cohort }\end{array}$ & Influenza A and B & 254 & 196 (77\%) & [103] \\
\hline
\end{tabular}

${ }^{\text {a }} \mathrm{TCID}_{50}: 50 \%$ tissue-culture infectious dose. ${ }^{\mathrm{b}}$ Participants were lost to follow-up.

Overall, the correlation between the initial infection dose, disease severity, and antibody development is a challenge to address in any naturally-acquired infection studies due to difficulties in determining the time of infection. Although the time and infection doses 
are predetermined in LAIV and human challenge studies, for ethical considerations, the viruses used are usually attenuated, or inoculated at doses that do not induce significant symptoms. As such, the relationship between the initial infection dose, symptom severity, and the subsequent downstream antibody response in humans is not well-established and can only be inferred from animal studies.

\section{Biological Factors That Influence Antibody Non-Responsiveness}

\subsection{Age: Immunosenescence, Frailty}

In children, poor vaccine responses have been attributed to a lack of priming, hence two doses have been recommended for children younger than 12 years of age in many countries [106]. However, factors underlying poor vaccine responses in the elderly, considered to be 60 years and above, are more complicated. A quantitative review of 31 studies using IIV found lower seroprotection and seroconversion rates in the elderly compared to adults, although, notably, this was more evident for $\mathrm{A}(\mathrm{H} 3 \mathrm{~N} 2)$ compared to $\mathrm{A}(\mathrm{H} 1 \mathrm{~N} 1)$ and IBV, with heterogeneity observed across the different studies [107]. However, a number of studies also reported no differences [108] or better responses compared to adults [109].

Post-vaccination antibody response failures in the elderly have been classified either as failure to mount antibody response within four weeks of vaccination (primary failure) or inability to sustain a post-vaccination antibody response (secondary failure) [109]. In these cases, the decline in vaccine-induced immune response in the elderly has been in part, attributed to the age-associated decline in innate and adaptive immune response, or immunosenescence $[110,111]$. Specifically, the expression of co-stimulatory molecules CD80 and CD86 on monocytes [112], and their downstream receptors CD28 on T-cells have been implicated in the impaired influenza vaccine responses in the elderly. Intrinsic defects in the B-cell compartment, including the impaired activity of the activation-induced cytidine deaminase (AID) that is required for class-switching memory B cells, decreased diversity and plasticity of the B-cell receptor repertoires, and shorter B cell telomere length may also contribute to the reduced immune response in the elderly [113-117]. Moreover, older adults develop fewer de novo immunoglobulin gene somatic mutations, which suggests a limited capacity to respond to novel antigens [118].

In addition to immunosenescence, frailty, a geriatric syndrome which is characterized by increased vulnerability to adverse health outcomes and multi-system dysregulation, has also been proposed to affect vaccine-induced antibody response in the elderly [119]. Some studies have demonstrated that vaccine-induced antibody response and vaccine effectiveness decreased as frailty increased [120,121], others reported no differences [122-124], while Loeb et al., using an approach that treated frailty as a continuous variable, found that antibody responses were positively associated with frailty after high-dose vaccination [125]. These inconsistent results may highlight the difficulty in classifying frailty, particularly at an immunological level.

\subsection{Prior Immunity: Repeat Vaccination, Immune Priming, and Imprinting}

It is now becoming clear that pre-existing influenza immunity can influence the antibody responses after influenza vaccination and infection in different ways. One consistent observation across vaccine trials is that while higher preexisting HAI-titers to the vaccine strain correlated with greater odds of achieving seroprotective titer, it is inversely correlated to seroconversions [3].

The constant strain updates to influenza vaccine composition and the recommendation for annual vaccination represents a particularly unique challenge for influenza. After repeated influenza vaccination, the serological response to recent vaccination may decrease. Repeat-influenza vaccination can result in higher baseline titers and lower magnitude fold changes, particularly when the vaccine strains were unchanged $[126,127]$. Importantly, reduced immunogenicity after repeated vaccination did not appear to be associated with reduced protection [128], likely because seroprotective titers were already present or protection was mediated by non-HAI-antibodies. 
As early as 1960, Thomas Francis Jr and his colleagues observed that the antibody response to influenza virus strains in childhood predominated during subsequent infections by antigenically related strains, a phenomenon he called original antigenic sin (OAS) [129]. Since then, studies have shown that the highest magnitude antibody responses are elicited to strains circulating within the first 10 years of life, and antibodies are elicited in a hierarchical manner to subsequently circulating strains, or "antigenic seniority". This suggests that early-life exposure will determine the pool of memory B-cells available to be recalled during subsequent exposures. Indeed, a recent study demonstrated that $60 \%$ of monoclonal antibodies elicited after influenza infection displayed equal or stronger affinity to childhood strains, indicating a strong bias of recall memory response from childhood exposures [16]. The effects of OAS can be reflected in the HAI and NA inhibiting (NAI)-antibodies as well as the HA-IgG antibodies responses [130].

How do pre-existing influenza antibodies influence the subsequent profile of antibody response? A recent informative study by Dugan et al. characterized the monoclonal antibodies derived from plasmablasts induced after infection and vaccination and found that only an average of $29 \%$ of antibodies elicited after an infection has in vitro virusneutralizing activity, compared to $80 \%$ of antibodies that were elicited after vaccination. The non-neutralizing antibodies induced after infection target more conserved epitopes such as HA-stem, NA, and NP, and other as yet unidentified epitopes. Interestingly, they noted differences in the H1N1 and H3N2 responses; H3N2 were more likely to elicit cross-reactive antibody responses compared to H1N1, which they attributed to the more rapid evolution of H3N2 viruses [16]. Andrews et al. showed that individuals with low preexisting serum HAI-titers generated more stem reactive plasmablasts after vaccination, while those with HAI titers $>40$ were associated with the generation of more HA-head targeting plasmablasts [38]. Incidentally, antibodies targeting the stem domains are most enriched during infection or vaccination with antigenically-shifted strains or strains with divergent HA-globular heads. Collectively, these studies demonstrate that each new exposure demonstrates a bias in recalling pre-existing memory B-cells, which with repeated exposures, may be enriched against conserved epitopes that have less potent neutralizing activity. Incidentally, however, pre-existing antibodies can also bind to such epitopes (epitope-masking), reducing antigen availability for subsequent antigen presentation [131]. It is important to note, however, that OAS has not been shown to impede the development of de novo antibodies, as greater increases in antibody titers are typically detected against the immunizing antigens [132,133].

The number of exposures and age are therefore important determinants on the influenza antibody landscape, used here to describe the totality of influenza antibody response. The elderly ( $\geq 65$ years old) will have the most influenza exposures, and correspondingly, have been shown to possess the highest baseline levels of HA-stem and NA-antibodies compared to other age groups $[134,135]$. Indeed, using an influenza virus protein microarray, Meade et al. found that children under 6 years of age had a narrow $\lg G$ and $\lg \mathrm{A}$ antibody response while adults showed a broad recall response [136]. Age can also influence the antibody dynamics to HA and NA in a strain-specific manner; adults are more likely to show either a HA- or NA-dominant response compared to children after influenza A, but not influenza B virus infections [137]. Since non-HAI antibodies have been identified as additional correlates of protection, it is important to therefore understand their recall dynamics. Efforts are currently underway to incorporate these assays as standard endpoints in influenza studies $[138,139]$. 


\subsection{Sex-Based Differences}

Although sex and gender can both influence influenza disease pathogenesis and the immune response, here we discuss only the role of sex as a biological construct and its effect on the influenza antibody responses. Epidemiologic data revealed females and males had different morbidity and mortality against seasonal, avian, and pandemic influenza in an age-dependent manner [140,141], suggesting a potential sex-based bias in the host immune response. Sex-based differences in antibody response have been better described in post-influenza vaccination antibody responses. Several studies found that females across different age groups developed stronger antibody responses following seasonal influenza vaccination compared to males $[140,142-144]$. Vaccine effectiveness was also greater in females than males, especially against influenza A(H3N2) and IBV (Victoria) strains [145]. Higher concentrations of inflammatory cytokines, such as Granulocyte macrophage-colony stimulating factor (GM-CSF), Interleukin (IL)-5, and IL-6 were detected after influenza vaccination in females compared to males [146,147]. Transcriptomics studies of gene expression after vaccination revealed greater expression of genes related to the immune response in females within $24 \mathrm{~h}$, although it was not indicated whether this cohort demonstrated different post-vaccination antibody responses [148]. Older females had significant differences in their NK, T- and B-cells gene expression in which the latter correlated with the development of higher memory B-cells responses as measured by ELISPOT assay, compared to males [149].

The underlying sex-based differences in antibody response have been attributed primarily to the influence of sex hormones and genetic factors. For example, immuneregulatory genes such as $I L 13 r \alpha 2$ and Tlr 7 are encoded on the sex-chromosomes [150,151], and high testosterone levels have been reported to suppress vaccination responses in males [146], although this has also been disputed [152]. A positive correlation between concentrations of estradiol and the antibody response has been observed in females [146,147]. The influence of sex hormones during the different life stages could also explain age-specific immune responses [147,153].

Small animal models have been used to recapitulate these sex-based differences. Female mice show greater $\mathrm{CD}^{+} \mathrm{T}$ and B-cell proliferation and developed more robust neutralizing antibody and total IgG responses compared to male mice following influenza vaccination [154-159]. Estradiol has also been reported to restore antibody responses in a postmenopausal mouse model immunized with a $\mathrm{A}(\mathrm{H} 1 \mathrm{~N} 1)$ vaccine, suggesting an underlying role for sex steroids in the sex-base differences observed in antibody responses [160]. An exception is that adult human males (18 to 64 years old) showed a greater proportion of high-avidity antibodies after monovalent 2009 A(H1N1) pandemic vaccination compared to age-matched females [160], although this observation has not been replicated in mice [156-158].

There is little evidence on differences in the sex-based antibody response after influenza virus infection in humans although, female mice generated more neutralizing antibodies and total anti-influenza antibodies than male mice after infection with $\mathrm{A}(\mathrm{H} 1 \mathrm{~N} 1)$ or A(H3N2) [161]. Moreover, female mice developed greater cross-protection against heterosubtypic influenza virus compared to males [161]. Incidentally, female mice are reported to be susceptible to more severe infections compared to male mice [162,163].

The evidence remains controversial on sex-based differences in the immune response to influenza in humans. Some studies have found differences at cellular but not soluble antibody levels; that is, sex-based differences in plasmablasts and B-cells responses but not in HAI-titers, suggesting potential sex-based differences in the proliferation and secretory response of the humoral immune response [149,164]. Whilst some epidemiological and animal studies have provided convincing evidence, the underlying mechanisms and relative contribution of sex within the context of other factors to antibody responses need to be resolved. 


\subsection{Genetics}

While host-genetic factors have been associated with influenza pathogenesis [165], less is known about its direct impact on antibody responses. A recent study found that genetic polymorphism in Interferon-induced transmembrane protein 3 (IFITM3), were associated with the magnitude of the antibody response after seasonal influenza vaccination [166]. Individuals with IFITM3 rs12252-C/C genotype had lower post-vaccination seroconversion rates compared with $\mathrm{C} / \mathrm{T}$ and $\mathrm{T} / \mathrm{T}$ donors. Poorer antibody responses were also detected in the Ifitm3- / - mouse model compared to wild-type. IFITM3 rs12252-C/C were also reported to be associated with severe influenza, presumably due to a truncated IFITM3 protein with reduced antiviral potency $[167,168]$, although others found no such association $[169,170]$. However, the IFITM3 rs12252 allele is only one of several elements in the interferon signaling pathway that has been associated with influenza clinical severity $[171,172]$. Given that the human interferon-system is such a critical modulator of the immune responses and is the common element that was associated with robust antibody responses after infection or vaccination, it would be important to explore further the contribution of these genetic polymorphisms to antibody responses.

\subsection{Chronic Infections}

\subsubsection{Cytomegalovirus (CMV)}

Cytomegalovirus (CMV) is a $\beta$-herpesvirus that infects between $40-100 \%$ of the adult population worldwide, establishing lifelong latency. Seropositivity within the population increases with age, with most studies reporting at least $60 \%$ seropositivity in those aged 50 years and above [173].

CMV is postulated to modulate host immunity via two mechanisms; a direct effect of the viral proteins, and, inducing a state of chronic inflammation during reactivation. Aside from inducing the expression of human IL-10 during infection, the CMV genome encodes cmvIL10, a human IL-10 homolog whose expression may differ during acute or latent infections. Like the human IL-10, cmvIL10 has a broad range of immunomodulatory functions, particularly on myeloid cells, which also serve as a latent reservoir for the virus. It has been reported to inhibit the maturation and function of DCs and down-regulate the expression of MHC Class II on myeloid cells, all of which are detrimental to antigen presentation $[174,175]$. Reactivation of CMV can lead to a state of chronic inflammation, postulated to lead to "exhaustion" of various immune cell populations [176]. CMV infection in humans is also linked to increased concentrations of immune-modulatory cytokines in the blood, such as TNF $\alpha$, IL10, and IL-6 [177-179].

CMV serostatus also has implications for B and T-cell populations and their responses to vaccination. A negative association has been found between CMV-seropositivity and predictive biomarkers of optimal vaccine responses in B-cells, namely switched memory B cells and activation-induced cytidine deaminase (AID) [180-183]. Further, CMV-seropositivity has a large effect on $\mathrm{CD}^{+}$and $\mathrm{CD} 8^{+} \mathrm{T}$-cell subsets at all ages in healthy individuals [184]. $\mathrm{CMV}$ infection primarily results in the accumulation of late-differentiated memory T-cells, both in the $\mathrm{CD}^{+}$and CD8 ${ }^{+}$T-cell lineage [185-187], which have limited capacity to respond to novel antigens. The late-stage differentiated memory T-cells that accumulate in the elderly, especially the $\mathrm{CD}^{+} \mathrm{T}$-cells, are frequently CMV-specific. Their eventual loss may be associated with incipient mortality [188]. A similar phenomenon has also been observed in $\mathrm{CD}^{+} \mathrm{T}$-cells, where $\mathrm{CMV}$-associated accumulations of late-stage memory cells and reduced naive cells have also been reported [189]. Many studies have shown that these factors are associated with a poor immune response to influenza [190-193].

Some studies have shown that CMV-seropositivity negatively correlates with postinfluenza vaccination antibody responses [180,194-196], while others found no correlation $[195,197,198]$. One study described an age-specific effect, whereby CMV infection enhanced post-influenza vaccination responses in the young but not the old [199]. Latent $\mathrm{CMV}$ can be reactivated during conditions of immunosuppression or inflammatory stress due to infections or critical illness [200]. Reactivation of CMV and Herpes simplex virus 
type-1 (HSV-1) have been reported in critically ill A(H7N9) patients [201,202]. Given its importance in modulating the immune response, how common herpesvirus reactivations are and the consequences on host immunity have not been directly examined in the context of influenza virus infections, particularly in immunocompetent hosts. The lack of consensus on the significance of CMV to influenza vaccination and infection is attributed in part to the difficulty in detecting active CMV infections, and the functional consequence of being CMV-seropositive [203]. More research is needed to clarify the relationship between CMV and influenza virus infection and immunity.

\subsubsection{Human Immunodeficiency Virus (HIV)}

As with CMV, there are conflicting accounts on the relationship between human immunodeficiency virus (HIV) infection and influenza immunity. Antibody responses to influenza are observed to be relatively poor in HIV-positive patients [204-209], likely due to the presence of low numbers of CD4 $4^{+}$T-cells and viremia [207,210,211]. Overall, there is limited data on the clinical effects of influenza vaccination in the context of HIV, however, it is important to address this as HIV patients are a high-risk group for influenza.

\section{Technical Factors: Choice of Assays, Antigens, and Samples}

Whilst biological factors can cause poor antibody responses after influenza virus infection and vaccination, virological or technical factors can lead to reduced assay sensitivity or false-negative or false-positive results. Due to the importance of HAI-antibodies and the relative ease of use, HAI-assays have been the serological workhorse in the field. However, HAI-assays have technical limitations. For example, the utility and sensitivity of this assay depend on the agglutination of red-blood cells (RBCs) by the virus. Adaptive HA mutations can alter sialic acid binding specificity and thus binding to RBCs, impacting the results of HAI assays. This can be overcome by using RBCs from other species than chicken, which are most commonly used, owing to species differences in the expression of sialic acids on RBCs [212]. For example, horse RBCs can increase the detection sensitivity of antibodies against avian influenza viruses $[213,214]$, while guinea pig and human O-type RBCs are recommended for seasonal influenza viruses [215]. Incidentally, most recently isolated $\mathrm{A}(\mathrm{H} 3 \mathrm{~N} 2)$ influenza viruses have HA mutations abrogating RBC binding, necessitating the adoption of alternative assays such as microneutralization or foci-reduction neutralization assays that do not rely on RBCs [216]. Although not as commonly used, single-radial hemolysis (SRH) is are also considered a gold standard in influenza immunogenicity evaluations by some regulatory bodies. Because it relies on complements to cause hemolysis, SRH can be used to detect complement activating influenza antibodies. These serological assays, along with ELISAs are capable of detecting influenza antibodies with different functional properties and generally show good correlations to one another in a robust antibody response $[217,218]$.

The method of antigen preparation can also influence serological observations. For example, using ether-treated IBVs as antigens in the HAI assay resulted in higher detection sensitivity, albeit at slightly lower specificity, compared to non-treated antigens [219]. Egg-grown influenza viruses used in the production of most influenza vaccines can also be antigenically distinct from cell-grown viruses, which are more similar to circulating strains [220] since egg-grown viruses can acquire egg-adaptive mutations that impact antigenicity [221,222].

It is becoming evident that the different classes of influenza antibodies beyond those detected by HAI-assays are functionally important and should also be considered as part of influenza antibody responses. Our study in New Zealand found that the inclusion of NAI-assay into the serodiagnosis platform increased the detection sensitivity of capturing influenza cases in the seroepidemiologic study [223]. The commonly used method to measure NAI antibodies is the enzyme-linked lectin assay (ELLA), which was originally developed by Lambre et al. [224]. It measures the degree of serum inhibition of NA-enzymatic activity using fetuin as a substrate. Compared with the traditional thiobar- 
bituric acid (TBA) method described by Webster and Laver [225], this method offered the advantages of being scaleable, safe, and specific [226]. Another NAI assay relies on the enzymatic cleavage of smaller substrates; either the fluorescent $2^{\prime}$-(4-Methylumbelliferyl)$\alpha$-D-N-acetylneuraminic acid (MUNANA) assay [227] or the chemiluminescent NA-STAR assay [228]. Because of the small substrates, NAI-antibodies detected using the MUNANA or NA-STAR assays are thought to only bind near the enzyme's active site.

It should also be mentioned that new assays are being developed to detect influenza antibodies. One such approach is the use of pseudoviruses bearing target influenza antigens. There are now many systems employed to produce these pseudoviruses [229]. The major advantages of using pseudoviruses are its safety, which is particularly relevant when expressing antigens from highly pathogenic avian influenza viruses, and its ability to express specific peptides, such as the HA-stem and M2. This enables the detection of antibodies targeting these epitopes that are normally inaccessible on wild-type viruses. The challenge remains in validating and standardizing these assays to current serological standards as they have shown variable performance in several comparative studies [218,230].

Therefore, the choice of an assay to measure these antibodies are not only qualitatively important, but can also reflect the dynamics that underlie the human immunological memory of influenza viruses. Finally, sampling technicalities could also impact the detection sensitivity for any antibody response. Appropriate time of sampling, sampling methods, and sample treatments could also affect the sensitivity in detecting seroconversion events [231].

Serum is considered the best specimen of choice for serologic assays. Compared to serum, plasma contained anticoagulants that can sometimes interfere with antibodyantigen interaction. HI titers were higher against influenza B in plasma, causing the overestimation and underestimation of the seropositive rates [232]. In general, however, there is a high degree correlation for $\mathrm{HI}$ and neutralization assays against influenza A between serum and plasma, which indicated that plasma can be used as an alternative specimen of choice for these assays, where convenient or necessary [232,233]. Appropriate sample treatment to remove non-specific inhibitors in human and animal sera is also crucial for accurate results. For HI assay, several treatment protocols are available although none of it worked universally across strains and species [234]. Treatment with receptor destroying enzyme (RDE) from Vibrio cholerae and heat-inactivation is presently recommended as part of the standard WHO HI protocol [215]. For an in-depth review of the serologic assays for influenza, we recommend reference [235].

\section{Conclusions}

Studying the immunogenicity of the influenza virus is complicated due to the large diversity of antigenic variants present in nature and our constant exposure to it, either through natural infection or vaccination. We have attempted to provide an up-to-date, although by no means comprehensive overview of factors that may influence influenza antibody responses and our ability to measure it (summarized in Figure 1). The biological factors described here may not be specific to influenza antibody responses and often do not occur independently. Some of the factors may even converge in a person's lifetime, i.e., chronic infections, number of exposures, and advancing age. How such factors interact and importantly, their relative contributions to the immunological response to influenza during infection and vaccination should be considered. Furthermore, recent advances demonstrating the importance of looking beyond HA-based immunity will likely change serological standards in influenza studies. This will provide a more comprehensive picture of what influenza immunogenicity, antibody responses, and protection mean. Such knowledge is vital to the design of improved vaccines or targeted vaccination programs against influenza. 


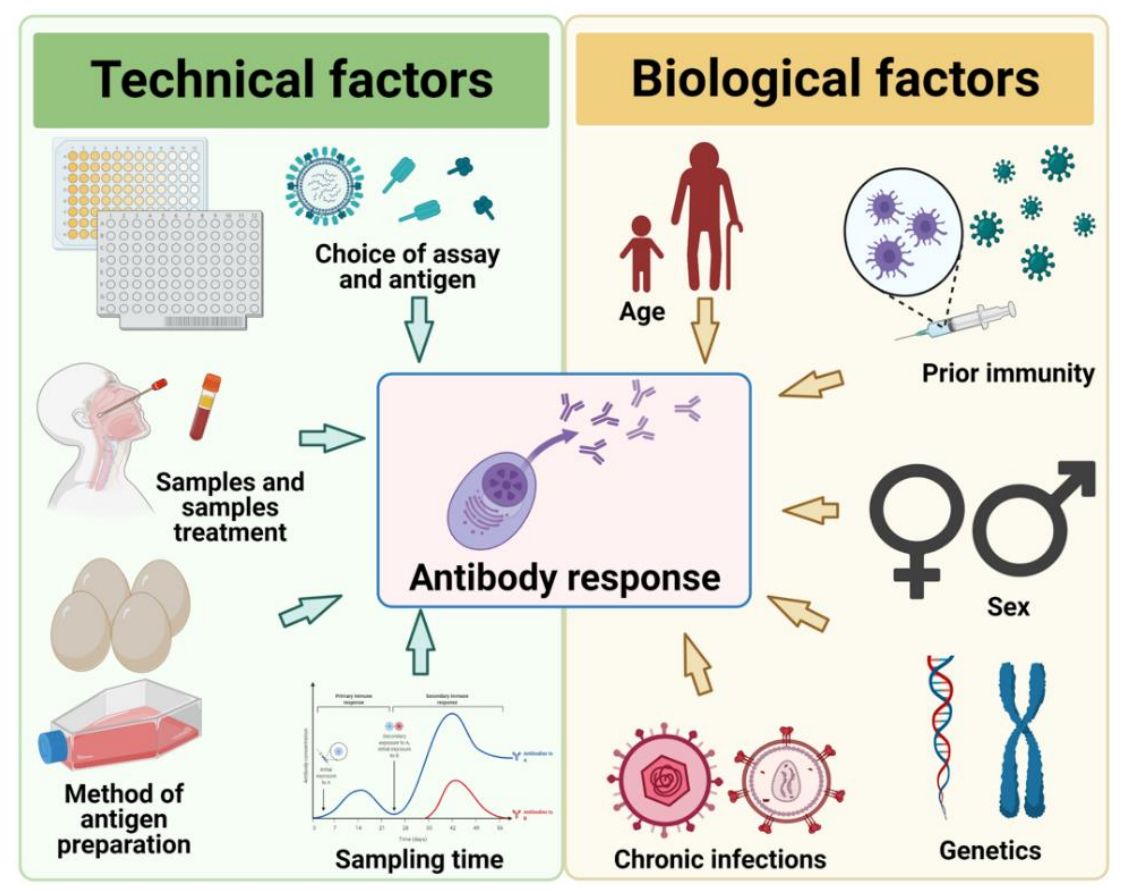

Figure 1. An overview of the biological and technical factors discussed in this review.

Author Contributions: Study conceptualization, S.-S.W. and M.Z.; Writing, literature review and original draft preparation, X.L., T.L. and F.L.; writing, re-viewing, and editing, X.L., M.F.D., M.Z. and S.-S.W.; funding acquisition, S.-S.W. All authors have read and agreed to the published version of the manuscript.

Funding: This research was funded by Natural Science Foundation of Guangdong Province, China, (Grant number 2019A1515012070). M.Z. and S.-S.W. are supported by the High-Level University Talent Construction Program of Guangzhou Medical University (Grant numbers: 06-410-2106093, 06-410-2106092).

Institutional Review Board Statement: Not applicable.

Informed Consent Statement: Not applicable.

Data Availability Statement: Not applicable.

Acknowledgments: We gratefully acknowledge Cheng Xiao of Guangzhou Medical University for her assistance in preparing the figures for this manuscript. Figure 1 was created with Biorender.com.

Conflicts of Interest: The authors declare no conflict of interest.

\section{References}

1. Iuliano, A.D.; Roguski, K.M.; Chang, H.H.; Muscatello, D.J.; Palekar, R.; Tempia, S.; Cohen, C.; Gran, J.M.; Schanzer, D.; Cowling, B.J.; et al. Estimates of global seasonal influenza-associated respiratory mortality: A modelling study. Lancet 2018, 391, 1285-1300. [CrossRef]

2. Krammer, F.; Smith, G.J.D.; Fouchier, R.A.M.; Peiris, M.; Kedzierska, K.; Doherty, P.C.; Palese, P.; Shaw, M.L.; Treanor, J.; Webster, R.G.; et al. Influenza. Nat. Rev. Dis. Primers 2018, 4, 3. [CrossRef] [PubMed]

3. Cox, R.J. Correlates of protection to influenza virus, where do we go from here? Hum. Vaccines Immunother. 2013, 9, 405-408. [CrossRef] [PubMed]

4. Thompson, W.W.; Shay, D.K.; Weintraub, E.; Brammer, L.; Cox, N.; Anderson, L.J.; Fukuda, K. Mortality associated with influenza and respiratory syncytial virus in the United States. JAMA 2003, 289, 179-186. [CrossRef]

5. Taubenberger, J.K.; Kash, J.C.; Morens, D.M. The 1918 influenza pandemic: 100 years of questions answered and unanswered. Sci. Transl. Med. 2019, 11. [CrossRef] [PubMed]

6. Pulendran, B.; Maddur, M.S. Innate immune sensing and response to influenza. Curr. Top. Microbiol. Immunol. 2015, 386, 23-71. [CrossRef] [PubMed]

7. Wille, M.; Holmes, E.C. The Ecology and Evolution of Influenza Viruses. Cold Spring Harb. Perspect. Med. 2020, 10. [CrossRef] [PubMed] 
8. Sicca, F.; Neppelenbroek, S.; Huckriede, A. Effector mechanisms of influenza-specific antibodies: Neutralization and beyond. Expert Rev. Vaccines 2018, 17, 785-795. [CrossRef]

9. Andrews, S.F.; Chambers, M.J.; Schramm, C.A.; Plyler, J.; Raab, J.E.; Kanekiyo, M.; Gillespie, R.A.; Ransier, A.; Darko, S.; Hu, J.; et al. Activation Dynamics and Immunoglobulin Evolution of Pre-existing and Newly Generated Human Memory B cell Responses to Influenza Hemagglutinin. Immunity 2019, 51, 398-410 e5. [CrossRef]

10. Wang, B.; Russell, M.L.; Brewer, A.; Newton, J.; Singh, P.; Ward, B.J.; Loeb, M. Single radial haemolysis compared to haemagglutinin inhibition and microneutralization as a correlate of protection against influenza A H3N2 in children and adolescents. Influenza Other Respir. Viruses 2017, 11, 283-288. [CrossRef]

11. Kreijtz, J.H.; Fouchier, R.A.; Rimmelzwaan, G.F. Immune responses to influenza virus infection. Virus Res. 2011, 162, 19-30. [CrossRef]

12. Park, J.K.; Han, A.; Czajkowski, L.; Reed, S.; Athota, R.; Bristol, T.; Rosas, L.A.; Cervantes-Medina, A.; Taubenberger, J.K.; Memoli, M.J. Evaluation of Preexisting Anti-Hemagglutinin Stalk Antibody as a Correlate of Protection in a Healthy Volunteer Challenge with Influenza A/H1N1pdm Virus. mBio 2018, 9. [CrossRef]

13. Yassine, H.M.; Boyington, J.C.; McTamney, P.M.; Wei, C.J.; Kanekiyo, M.; Kong, W.P.; Gallagher, J.R.; Wang, L.; Zhang, Y.; Joyce, M.G.; et al. Hemagglutinin-stem nanoparticles generate heterosubtypic influenza protection. Nat. Med. 2015, 21, 1065-1070. [CrossRef]

14. Yamayoshi, S.; Kawaoka, Y. Current and future influenza vaccines. Nat. Med. 2019, 25, 212-220. [CrossRef]

15. Zanin, M.; Marathe, B.; Wong, S.S.; Yoon, S.W.; Collin, E.; Oshansky, C.; Jones, J.; Hause, B.; Webby, R. Pandemic Swine H1N1 Influenza Viruses with Almost Undetectable Neuraminidase Activity Are Not Transmitted via Aerosols in Ferrets and Are Inhibited by Human Mucus but Not Swine Mucus. J. Virol. 2015, 89, 5935-5948. [CrossRef]

16. Dugan, H.L.; Guthmiller, J.J.; Arevalo, P.; Huang, M.; Chen, Y.Q.; Neu, K.E.; Henry, C.; Zheng, N.Y.; Lan, L.Y.; Tepora, M.E.; et al. Preexisting immunity shapes distinct antibody landscapes after influenza virus infection and vaccination in humans. Sci. Transl. Med. 2020, 12. [CrossRef]

17. Eichelberger, M.C.; Morens, D.M.; Taubenberger, J.K. Neuraminidase as an influenza vaccine antigen: A low hanging fruit, ready for picking to improve vaccine effectiveness. Curr. Opin. Immunol. 2018, 53, 38-44. [CrossRef]

18. Chen, Y.Q.; Wohlbold, T.J.; Zheng, N.Y.; Huang, M.; Huang, Y.; Neu, K.E.; Lee, J.; Wan, H.; Rojas, K.T.; Kirkpatrick, E.; et al. Influenza Infection in Humans Induces Broadly Cross-Reactive and Protective Neuraminidase-Reactive Antibodies. Cell 2018, 173, 417-429. [CrossRef]

19. Couch, R.B.; Atmar, R.L.; Franco, L.M.; Quarles, J.M.; Wells, J.; Arden, N.; Nino, D.; Belmont, J.W. Antibody correlates and predictors of immunity to naturally occurring influenza in humans and the importance of antibody to the neuraminidase. J. Infect. Dis. 2013, 207, 974-981. [CrossRef]

20. Karunarathna, H.; Perera, R.; Fang, V.J.; Yen, H.L.; Cowling, B.J.; Peiris, M. Serum anti-neuraminidase antibody responses in human influenza A(H1N1)pdm09 virus infections. Emerg. Microbes Infect. 2019, 8, 404-412. [CrossRef]

21. Monto, A.S.; Petrie, J.G.; Cross, R.T.; Johnson, E.; Liu, M.; Zhong, W.; Levine, M.; Katz, J.M.; Ohmit, S.E. Antibody to Influenza Virus Neuraminidase: An Independent Correlate of Protection. J. Infect. Dis. 2015, 212, 1191-1199. [CrossRef]

22. Gilbert, P.B.; Fong, Y.; Juraska, M.; Carpp, L.N.; Monto, A.S.; Martin, E.T.; Petrie, J.G. HAI and NAI titer correlates of inactivated and live attenuated influenza vaccine efficacy. BMC Infect. Dis. 2019, 19, 453. [CrossRef]

23. Stadlbauer, D.; Zhu, X.; McMahon, M.; Turner, J.S.; Wohlbold, T.J.; Schmitz, A.J.; Strohmeier, S.; Yu, W.; Nachbagauer, R.; Mudd, P.A.; et al. Broadly protective human antibodies that target the active site of influenza virus neuraminidase. Science 2019, 366, 499-504. [CrossRef]

24. Jagadesh, A.; Salam, A.A.; Mudgal, P.P.; Arunkumar, G. Influenza virus neuraminidase (NA): A target for antivirals and vaccines. Arch. Virol. 2016, 161, 2087-2094. [CrossRef]

25. Rijal, P.; Wang, B.B.; Tan, T.K.; Schimanski, L.; Janesch, P.; Dong, T.; McCauley, J.W.; Daniels, R.S.; Townsend, A.R.; Huang, K.A. Broadly Inhibiting Antineuraminidase Monoclonal Antibodies Induced by Trivalent Influenza Vaccine and H7N9 Infection in Humans. J. Virol. 2020, 94. [CrossRef]

26. Wohlbold, T.J.; Krammer, F. In the shadow of hemagglutinin: A growing interest in influenza viral neuraminidase and its role as a vaccine antigen. Viruses 2014, 6, 2465-2494. [CrossRef]

27. Krammer, F.; Fouchier, R.A.M.; Eichelberger, M.C.; Webby, R.J.; Shaw-Saliba, K.; Wan, H.; Wilson, P.C.; Compans, R.W.; Skountzou, I.; Monto, A.S. NAction! How Can Neuraminidase-Based Immunity Contribute to Better Influenza Virus Vaccines? mBio 2018, 9. [CrossRef]

28. Zebedee, S.L.; Richardson, C.D.; Lamb, R.A. Characterization of the influenza virus M2 integral membrane protein and expression at the infected-cell surface from cloned cDNA. J. Virol. 1985, 56, 502-511. [CrossRef]

29. Lamb, R.A.; Lai, C.J.; Choppin, P.W. Sequences of mRNAs derived from genome RNA segment 7 of influenza virus: Colinear and interrupted mRNAs code for overlapping proteins. Proc. Natl. Acad. Sci. USA 1981, 78, 4170-4174. [CrossRef] [PubMed]

30. Pinto, L.H.; Holsinger, L.J.; Lamb, R.A. Influenza virus M2 protein has ion channel activity. Cell 1992, 69, 517-528. [CrossRef]

31. De Filette, M.; Min Jou, W.; Birkett, A.; Lyons, K.; Schultz, B.; Tonkyro, A.; Resch, S.; Fiers, W. Universal influenza A vaccine: Optimization of M2-based constructs. Virology 2005, 337, 149-161. [CrossRef] [PubMed] 
32. Van den Hoecke, S.; Ehrhardt, K.; Kolpe, A.; El Bakkouri, K.; Deng, L.; Grootaert, H.; Schoonooghe, S.; Smet, A.; Bentahir, M.; Roose, K.; et al. Hierarchical and Redundant Roles of Activating FcgammaRs in Protection against Influenza Disease by M2e-Specific IgG1 and IgG2a Antibodies. J. Virol. 2017, 91. [CrossRef] [PubMed]

33. Lee, Y.N.; Lee, Y.T.; Kim, M.C.; Hwang, H.S.; Lee, J.S.; Kim, K.H.; Kang, S.M. Fc receptor is not required for inducing antibodies but plays a critical role in conferring protection after influenza M2 vaccination. Immunology 2014, 143, 300-309. [CrossRef] [PubMed]

34. Carragher, D.M.; Kaminski, D.A.; Moquin, A.; Hartson, L.; Randall, T.D. A novel role for non-neutralizing antibodies against nucleoprotein in facilitating resistance to influenza virus. J. Immunol. 2008, 181, 4168-4176. [CrossRef]

35. Memoli, M.J.; Shaw, P.A.; Han, A.; Czajkowski, L.; Reed, S.; Athota, R.; Bristol, T.; Fargis, S.; Risos, K.; Powers, J.H.; et al. Evaluation of Antihemagglutinin and Antineuraminidase Antibodies as Correlates of Protection in an Influenza A/H1N1 Virus Healthy Human Challenge Model. mBio 2016, 7, e00417-16. [CrossRef] [PubMed]

36. Davies, J.R.; Grilli, E.A. Natural or vaccine-induced antibody as a predictor of immunity in the face of natural challenge with influenza viruses. Epidemiol. Infect. 1989, 102, 325-333. [CrossRef]

37. Li, C.K.; Rappuoli, R.; Xu, X.N. Correlates of protection against influenza infection in humans-on the path to a universal vaccine? Curr. Opin. Immunol. 2013, 25, 470-476. [CrossRef] [PubMed]

38. Andrews, S.F.; Huang, Y.; Kaur, K.; Popova, L.I.; Ho, I.Y.; Pauli, N.T.; Henry Dunand, C.J.; Taylor, W.M.; Lim, S.; Huang, M.; et al. Immune history profoundly affects broadly protective B cell responses to influenza. Sci. Transl. Med. 2015, 7, 316ra192. [CrossRef] [PubMed]

39. Von Holle, T.A.; Moody, M.A. Influenza and Antibody-Dependent Cellular Cytotoxicity. Front. Immunol. 2019, 10, 1457. [CrossRef]

40. Sedova, E.S.; Scherbinin, D.N.; Lysenko, A.A.; Alekseeva, S.V.; Artemova, E.A.; Shmarov, M.M. Non-neutralizing Antibodies Directed at Conservative Influenza Antigens. Acta Nat. 2019, 11, 22-32. [CrossRef]

41. Vanderven, H.A.; Jegaskanda, S.; Wines, B.D.; Hogarth, P.M.; Carmuglia, S.; Rockman, S.; Chung, A.W.; Kent, S.J. AntibodyDependent Cellular Cytotoxicity Responses to Seasonal Influenza Vaccination in Older Adults. J. Infect. Dis. 2017, 217, 12-23. [CrossRef]

42. Jegaskanda, S.; Vanderven, H.A.; Tan, H.X.; Alcantara, S.; Wragg, K.M.; Parsons, M.S.; Chung, A.W.; Juno, J.A.; Kent, S.J. Influenza Virus Infection Enhances Antibody-Mediated NK Cell Functions via Type I Interferon-Dependent Pathways. J. Virol. $2019,93$. [CrossRef] [PubMed]

43. Jegaskanda, S.; Laurie, K.L.; Amarasena, T.H.; Winnall, W.R.; Kramski, M.; De Rose, R.; Barr, I.G.; Brooks, A.G.; Reading, P.C.; Kent, S.J. Age-associated cross-reactive antibody-dependent cellular cytotoxicity toward 2009 pandemic influenza A virus subtype H1N1. J. Infect. Dis. 2013, 208, 1051-1061. [CrossRef] [PubMed]

44. Zhong, W.; Gross, F.L.; Holiday, C.; Jefferson, S.N.; Bai, Y.; Liu, F.; Katz, J.M.; Levine, M.Z. Vaccination with $2014-15$ Seasonal Inactivated Influenza Vaccine Elicits Cross-Reactive Anti-HA Antibodies with Strong ADCC Against Antigenically Drifted Circulating H3N2 Virus in Humans. Viral Immunol. 2016, 29, 259-262. [CrossRef] [PubMed]

45. Terajima, M.; Co, M.D.; Cruz, J.; Ennis, F.A. High Antibody-Dependent Cellular Cytotoxicity Antibody Titers to H5N1 and H7N9 Avian Influenza A Viruses in Healthy US Adults and Older Children. J. Infect. Dis. 2015, 212, 1052-1060. [CrossRef]

46. Jegerlehner, A.; Schmitz, N.; Storni, T.; Bachmann, M.F. Influenza A vaccine based on the extracellular domain of M2: Weak protection mediated via antibody-dependent NK cell activity. J. Immunol. 2004, 172, 5598-5605. [CrossRef] [PubMed]

47. Hashimoto, Y.; Moki, T.; Takizawa, T.; Shiratsuchi, A.; Nakanishi, Y. Evidence for phagocytosis of influenza virus-infected, apoptotic cells by neutrophils and macrophages in mice. J. Immunol. 2007, 178, 2448-2457. [CrossRef]

48. He, W.; Chen, C.J.; Mullarkey, C.E.; Hamilton, J.R.; Wong, C.K.; Leon, P.E.; Uccellini, M.B.; Chromikova, V.; Henry, C.; Hoffman, K.W.; et al. Alveolar macrophages are critical for broadly-reactive antibody-mediated protection against influenza A virus in mice. Nat. Commun. 2017, 8, 846. [CrossRef] [PubMed]

49. Ana-Sosa-Batiz, F.; Vanderven, H.; Jegaskanda, S.; Johnston, A.; Rockman, S.; Laurie, K.; Barr, I.; Reading, P.; Lichtfuss, M.; Kent, S.J. Influenza-Specific Antibody-Dependent Phagocytosis. PLoS ONE 2016, 11, e0154461. [CrossRef]

50. Beebe, D.P.; Schreiber, R.D.; Cooper, N.R. Neutralization of influenza virus by normal human sera: Mechanisms involving antibody and complement. J. Immunol. 1983, 130, 1317-1322.

51. Jayasekera, J.P.; Moseman, E.A.; Carroll, M.C. Natural antibody and complement mediate neutralization of influenza virus in the absence of prior immunity. J. Virol. 2007, 81, 3487-3494. [CrossRef] [PubMed]

52. Rattan, A.; Pawar, S.D.; Nawadkar, R.; Kulkarni, N.; Lal, G.; Mullick, J.; Sahu, A. Synergy between the classical and alternative pathways of complement is essential for conferring effective protection against the pandemic influenza A(H1N1) 2009 virus infection. PLoS Pathog. 2017, 13, e1006248. [CrossRef]

53. El Bakkouri, K.; Descamps, F.; De Filette, M.; Smet, A.; Festjens, E.; Birkett, A.; Van Rooijen, N.; Verbeek, S.; Fiers, W.; Saelens, $X$. Universal vaccine based on ectodomain of matrix protein 2 of influenza A: Fc receptors and alveolar macrophages mediate protection. J. Immunol. 2011, 186, 1022-1031. [CrossRef] [PubMed]

54. Henry Dunand, C.J.; Leon, P.E.; Huang, M.; Choi, A.; Chromikova, V.; Ho, I.Y.; Tan, G.S.; Cruz, J.; Hirsh, A.; Zheng, N.Y.; et al. Both Neutralizing and Non-Neutralizing Human H7N9 Influenza Vaccine-Induced Monoclonal Antibodies Confer Protection. Cell Host Microbe 2016, 19, 800-813. [CrossRef] [PubMed] 
55. Kim, Y.J.; Kim, K.H.; Ko, E.J.; Kim, M.C.; Lee, Y.N.; Jung, Y.J.; Lee, Y.T.; Kwon, Y.M.; Song, J.M.; Kang, S.M. Complement C3 Plays a Key Role in Inducing Humoral and Cellular Immune Responses to Influenza Virus Strain-Specific Hemagglutinin-Based or Cross-Protective M2 Extracellular Domain-Based Vaccination. J. Virol. 2018, 92. [CrossRef]

56. Terajima, M.; Cruz, J.; Co, M.D.; Lee, J.H.; Kaur, K.; Wrammert, J.; Wilson, P.C.; Ennis, F.A. Complement-dependent lysis of influenza a virus-infected cells by broadly cross-reactive human monoclonal antibodies. J. Virol. 2011, 85, 13463-13467. [CrossRef]

57. Wu, Y.; Cho, M.; Shore, D.; Song, M.; Choi, J.; Jiang, T.; Deng, Y.Q.; Bourgeois, M.; Almli, L.; Yang, H.; et al. A potent broadspectrum protective human monoclonal antibody crosslinking two haemagglutinin monomers of influenza A virus. Nat. Commun. 2015, 6, 7708. [CrossRef]

58. Sridhar, S.; Begom, S.; Bermingham, A.; Hoschler, K.; Adamson, W.; Carman, W.; Bean, T.; Barclay, W.; Deeks, J.J.; Lalvani, A. Cellular immune correlates of protection against symptomatic pandemic influenza. Nat. Med. 2013, 19, 1305-1312. [CrossRef]

59. Wilkinson, T.M.; Li, C.K.; Chui, C.S.; Huang, A.K.; Perkins, M.; Liebner, J.C.; Lambkin-Williams, R.; Gilbert, A.; Oxford, J.; Nicholas, B.; et al. Preexisting influenza-specific $\mathrm{CD}^{+} \mathrm{T}$ cells correlate with disease protection against influenza challenge in humans. Nat. Med. 2012, 18, 274-280. [CrossRef]

60. Weinfurter, J.T.; Brunner, K.; Capuano, S.V., 3rd; Li, C.; Broman, K.W.; Kawaoka, Y.; Friedrich, T.C. Cross-reactive T cells are involved in rapid clearance of 2009 pandemic H1N1 influenza virus in nonhuman primates. PLoS Pathog. 2011, 7, e1002381. [CrossRef]

61. Gaucher, D.; Therrien, R.; Kettaf, N.; Angermann, B.R.; Boucher, G.; Filali-Mouhim, A.; Moser, J.M.; Mehta, R.S.; Drake, D.R., 3rd; Castro, E.; et al. Yellow fever vaccine induces integrated multilineage and polyfunctional immune responses. J. Exp. Med. 2008, 205, 3119-3131. [CrossRef]

62. Querec, T.D.; Akondy, R.S.; Lee, E.K.; Cao, W.; Nakaya, H.I.; Teuwen, D.; Pirani, A.; Gernert, K.; Deng, J.; Marzolf, B.; et al. Systems biology approach predicts immunogenicity of the yellow fever vaccine in humans. Nat. Immunol. 2009, 10, 116-125. [CrossRef]

63. Rao, S.; Ghosh, D.; Asturias, E.J.; Weinberg, A. What can we learn about influenza infection and vaccination from transcriptomics? Hum. Vaccines Immunother. 2019, 15, 2615-2623. [CrossRef] [PubMed]

64. Bucasas, K.L.; Franco, L.M.; Shaw, C.A.; Bray, M.S.; Wells, J.M.; Nino, D.; Arden, N.; Quarles, J.M.; Couch, R.B.; Belmont, J.W. Early patterns of gene expression correlate with the humoral immune response to influenza vaccination in humans. J. Infect. Dis. 2011, 203, 921-929. [CrossRef] [PubMed]

65. Nakaya, H.I.; Wrammert, J.; Lee, E.K.; Racioppi, L.; Marie-Kunze, S.; Haining, W.N.; Means, A.R.; Kasturi, S.P.; Khan, N.; Li, G.M.; et al. Systems biology of vaccination for seasonal influenza in humans. Nat. Immunol. 2011, 12, 786-795. [CrossRef] [PubMed]

66. Obermoser, G.; Presnell, S.; Domico, K.; Xu, H.; Wang, Y.; Anguiano, E.; Thompson-Snipes, L.; Ranganathan, R.; Zeitner, B.; Bjork, A.; et al. Systems scale interactive exploration reveals quantitative and qualitative differences in response to influenza and pneumococcal vaccines. Immunity 2013, 38, 831-844. [CrossRef] [PubMed]

67. Cao, R.G.; Suarez, N.M.; Obermoser, G.; Lopez, S.M.; Flano, E.; Mertz, S.E.; Albrecht, R.A.; Garcia-Sastre, A.; Mejias, A.; Xu, H.; et al. Differences in antibody responses between trivalent inactivated influenza vaccine and live attenuated influenza vaccine correlate with the kinetics and magnitude of interferon signaling in children. J. Infect. Dis. 2014, 210, 224-233. [CrossRef]

68. Nakaya, H.I.; Clutterbuck, E.; Kazmin, D.; Wang, L.; Cortese, M.; Bosinger, S.E.; Patel, N.B.; Zak, D.E.; Aderem, A.; Dong, T.; et al. Systems biology of immunity to MF59-adjuvanted versus nonadjuvanted trivalent seasonal influenza vaccines in early childhood. Proc. Natl. Acad. Sci. USA 2016, 113, 1853-1858. [CrossRef]

69. Tan, Y.; Tamayo, P.; Nakaya, H.; Pulendran, B.; Mesirov, J.P.; Haining, W.N. Gene signatures related to B-cell proliferation predict influenza vaccine-induced antibody response. Eur. J. Immunol. 2014, 44, 285-295. [CrossRef] [PubMed]

70. Furman, D.; Jojic, V.; Kidd, B.; Shen-Orr, S.; Price, J.; Jarrell, J.; Tse, T.; Huang, H.; Lund, P.; Maecker, H.T.; et al. Apoptosis and other immune biomarkers predict influenza vaccine responsiveness. Mol. Syst. Biol. 2013, 9, 659. [CrossRef] [PubMed]

71. Franco, L.M.; Bucasas, K.L.; Wells, J.M.; Nino, D.; Wang, X.; Zapata, G.E.; Arden, N.; Renwick, A.; Yu, P.; Quarles, J.M.; et al. Integrative genomic analysis of the human immune response to influenza vaccination. eLife 2013, 2, e00299. [CrossRef] [PubMed]

72. Zhai, Y.; Franco, L.M.; Atmar, R.L.; Quarles, J.M.; Arden, N.; Bucasas, K.L.; Wells, J.M.; Nino, D.; Wang, X.; Zapata, G.E.; et al. Host Transcriptional Response to Influenza and Other Acute Respiratory Viral Infections-A Prospective Cohort Study. PLoS Pathog. 2015, 11, e1004869. [CrossRef]

73. Ellebedy, A.H.; Jackson, K.J.; Kissick, H.T.; Nakaya, H.I.; Davis, C.W.; Roskin, K.M.; McElroy, A.K.; Oshansky, C.M.; Elbein, R.; Thomas, S.; et al. Defining antigen-specific plasmablast and memory B cell subsets in human blood after viral infection or vaccination. Nat. Immunol. 2016, 17, 1226-1234. [CrossRef] [PubMed]

74. Koutsakos, M.; Nguyen, T.H.O.; Kedzierska, K. With a Little Help from T Follicular Helper Friends: Humoral Immunity to Influenza Vaccination. J. Immunol. 2019, 202, 360-367. [CrossRef] [PubMed]

75. Wong, S.S.; Oshansky, C.M.; Guo, X.J.; Ralston, J.; Wood, T.; Reynolds, G.E.; Seeds, R.; Jelley, L.; Waite, B.; Jeevan, T.; et al Activated $\mathrm{CD} 4^{+} \mathrm{T}$ cells and $\mathrm{CD} 14^{\text {hi }} \mathrm{CD} 16^{+}$monocytes correlate with antibody response following influenza virus infection in humans. Cell Rep. Med. 2021, 100237. [CrossRef] [PubMed]

76. Rowntree, L.C.; Chua, B.Y.; Nicholson, S.; Koutsakos, M.; Hensen, L.; Douros, C.; Selva, K.; Mordant, F.L.; Wong, C.Y.; Habel, J.R.; et al. Robust correlations across six SARS-CoV-2 serology assays detecting distinct antibody features. Clin. Transl. Immunol. 2021, 10, e1258. [CrossRef] 
77. Koutsakos, M.; Rowntree, L.C.; Hensen, L.; Chua, B.Y.; van de Sandt, C.E.; Habel, J.R.; Zhang, W.; Jia, X.; Kedzierski, L.; Ashhurst, T.M.; et al. Integrated immune dynamics define correlates of COVID-19 severity and antibody responses. Cell Rep. Med. 2021, 2, 100208. [CrossRef]

78. Zhu, W.; Higgs, B.W.; Morehouse, C.; Streicher, K.; Ambrose, C.S.; Woo, J.; Kemble, G.W.; Jallal, B.; Yao, Y. A whole genome transcriptional analysis of the early immune response induced by live attenuated and inactivated influenza vaccines in young children. Vaccine 2010, 28, 2865-2876. [CrossRef] [PubMed]

79. Goncalves, E.; Bonduelle, O.; Soria, A.; Loulergue, P.; Rousseau, A.; Cachanado, M.; Bonnabau, H.; Thiebaut, R.; Tchitchek, N.; Behillil, S.; et al. Innate gene signature distinguishes humoral versus cytotoxic responses to influenza vaccination. J. Clin. Investig. 2019, 129, 1960-1971. [CrossRef]

80. Spensieri, F.; Borgogni, E.; Zedda, L.; Bardelli, M.; Buricchi, F.; Volpini, G.; Fragapane, E.; Tavarini, S.; Finco, O.; Rappuoli, R.; et al. Human circulating influenza-CD4 ${ }^{+} \mathrm{ICOS}^{+} \mathrm{IL}-21^{+} \mathrm{T}$ cells expand after vaccination, exert helper function, and predict antibody responses. Proc. Natl. Acad. Sci. USA 2013, 110, 14330-14335. [CrossRef]

81. Bentebibel, S.E.; Lopez, S.; Obermoser, G.; Schmitt, N.; Mueller, C.; Harrod, C.; Flano, E.; Mejias, A.; Albrecht, R.A.; Blankenship, D.; et al. Induction of ICOS+CXCR3+CXCR5+ TH cells correlates with antibody responses to influenza vaccination. Sci. Transl. Med. 2013, 5, 176ra32. [CrossRef] [PubMed]

82. Herati, R.S.; Reuter, M.A.; Dolfi, D.V.; Mansfield, K.D.; Aung, H.; Badwan, O.Z.; Kurupati, R.K.; Kannan, S.; Ertl, H.; Schmader, K.E.; et al. Circulating CXCR5+PD-1+ response predicts influenza vaccine antibody responses in young adults but not elderly adults. J. Immunol. 2014, 193, 3528-3537. [CrossRef] [PubMed]

83. Hobson, D.; Curry, R.L.; Beare, A.S.; Ward-Gardner, A. The role of serum haemagglutination-inhibiting antibody in protection against challenge infection with influenza A2 and B viruses. J. Hyg. 1972, 70, 767-777. [CrossRef]

84. Plotkin, S.; Robinson, J.M.; Cunningham, G.; Iqbal, R.; Larsen, S. The complexity and cost of vaccine manufacturing-An overview. Vaccine 2017, 35, 4064-4071. [CrossRef] [PubMed]

85. Couch, R.B.; Decker, W.K.; Utama, B.; Atmar, R.L.; Nino, D.; Feng, J.Q.; Halpert, M.M.; Air, G.M. Evaluations for in vitro correlates of immunogenicity of inactivated influenza a H5, H7 and H9 vaccines in humans. PLoS ONE 2012, 7, e50830. [CrossRef]

86. Belshe, R.B.; Frey, S.E.; Graham, I.L.; Anderson, E.L.; Jackson, L.A.; Spearman, P.; Edupuganti, S.; Mulligan, M.J.; Rouphael, N.; Winokur, P.; et al. Immunogenicity of avian influenza A/Anhui/01/2005(H5N1) vaccine with MF59 adjuvant: A randomized clinical trial. JAMA 2014, 312, 1420-1428. [CrossRef]

87. Jackson, L.A.; Campbell, J.D.; Frey, S.E.; Edwards, K.M.; Keitel, W.A.; Kotloff, K.L.; Berry, A.A.; Graham, I.; Atmar, R.L.; Creech, C.B.; et al. Effect of Varying Doses of a Monovalent H7N9 Influenza Vaccine With and Without AS03 and MF59 Adjuvants on Immune Response: A Randomized Clinical Trial. JAMA 2015, 314, 237-246. [CrossRef]

88. Mulligan, M.J.; Bernstein, D.I.; Winokur, P.; Rupp, R.; Anderson, E.; Rouphael, N.; Dickey, M.; Stapleton, J.T.; Edupuganti, S.; Spearman, P.; et al. Serological responses to an avian influenza A/H7N9 vaccine mixed at the point-of-use with MF59 adjuvant: A randomized clinical trial. JAMA 2014, 312, 1409-1419. [CrossRef]

89. Madan, A.; Segall, N.; Ferguson, M.; Frenette, L.; Kroll, R.; Friel, D.; Soni, J.; Li, P.; Innis, B.L.; Schuind, A. Immunogenicity and Safety of an AS03-Adjuvanted H7N9 Pandemic Influenza Vaccine in a Randomized Trial in Healthy Adults. J. Infect. Dis. 2016, 214, 1717-1727. [CrossRef]

90. Wong, S.S.; Kaplan, B.; Zanin, M.; Debeauchamp, J.; Kercher, L.; Crumpton, J.C.; Seiler, P.; Sun, Y.; Tang, L.; Krauss, S.; et al. Impact of Adjuvants on the Immunogenicity and Efficacy of Split-Virion H7N9 Vaccine in Ferrets. J. Infect. Dis. 2015, $212,542-551$. [CrossRef]

91. Caspard, H.; Mallory, R.M.; Yu, J.; Ambrose, C.S. Live-Attenuated Influenza Vaccine Effectiveness in Children from 2009 to 2015-2016: A Systematic Review and Meta-Analysis. Open Forum Infect. Dis. 2017, 4, ofx111. [CrossRef]

92. Lewis, K.D.C.; Ortiz, J.R.; Rahman, M.Z.; Levine, M.Z.; Rudenko, L.; Wright, P.F.; Katz, J.M.; Dally, L.; Rahman, M.; Isakova-Sivak, I.; et al. Immunogenicity and Viral Shedding of Russian-Backbone, Seasonal, Trivalent, Live, Attenuated Influenza Vaccine in a Phase II, Randomized, Placebo-Controlled Trial Among Preschool-Aged Children in Urban Bangladesh. Clin. Infect. Dis. 2019, 69, 777-785. [CrossRef]

93. Grohskopf, L.A.; Sokolow, L.Z.; Fry, A.M.; Walter, E.B.; Jernigan, D.B. Update: ACIP Recommendations for the Use of Quadrivalent Live Attenuated Influenza Vaccine (LAIV4)—United States, 2018-2019 Influenza Season. MMWR Morb. Mortal. Wkly Rep. 2018, 67, 643-645. [CrossRef] [PubMed]

94. Jackson, D.; Pitcher, M.; Hudson, C.; Andrews, N.; Southern, J.; Ellis, J.; Hoschler, K.; Pebody, R.; Turner, P.J.; Miller, E.; et al. Viral Shedding in Recipients of Live Attenuated Influenza Vaccine in the 2016-2017 and 2017-2018 Influenza Seasons in the United Kingdom. Clin. Infect. Dis. 2020, 70, 2505-2513. [CrossRef] [PubMed]

95. Memoli, M.J.; Czajkowski, L.; Reed, S.; Athota, R.; Bristol, T.; Proudfoot, K.; Fargis, S.; Stein, M.; Dunfee, R.L.; Shaw, P.A.; et al. Validation of the wild-type influenza A human challenge model H1N1pdMIST: An A(H1N1)pdm09 dose-finding investigational new drug study. Clin. Infect. Dis. 2015, 60, 693-702. [CrossRef] [PubMed]

96. Watson, J.M.; Francis, J.N.; Mesens, S.; Faiman, G.A.; Makin, J.; Patriarca, P.; Treanor, J.J.; Georges, B.; Bunce, C.J. Characterisation of a wild-type influenza (A/H1N1) virus strain as an experimental challenge agent in humans. Virol. J. 2015, 12, 13. [CrossRef] [PubMed] 
97. Han, A.; Czajkowski, L.M.; Donaldson, A.; Baus, H.A.; Reed, S.M.; Athota, R.S.; Bristol, T.; Rosas, L.A.; Cervantes-Medina, A.; Taubenberger, J.K.; et al. A Dose-finding Study of a Wild-type Influenza A(H3N2) Virus in a Healthy Volunteer Human Challenge Model. Clin. Infect. Dis. 2019, 69, 2082-2090. [CrossRef]

98. Clements, M.L.; O’Donnell, S.; Levine, M.M.; Chanock, R.M.; Murphy, B.R. Dose response of A/Alaska/6/77 (H3N2) coldadapted reassortant vaccine virus in adult volunteers: Role of local antibody in resistance to infection with vaccine virus. Infect. Immun. 1983, 40, 1044-1051. [CrossRef]

99. Brickley, E.B.; Wright, P.F.; Khalenkov, A.; Neuzil, K.M.; Ortiz, J.R.; Rudenko, L.; Levine, M.Z.; Katz, J.M.; Brooks, W.A. The Effect of Preexisting Immunity on Virus Detection and Immune Responses in a Phase II, Randomized Trial of a Russian-Backbone, Live, Attenuated Influenza Vaccine in Bangladeshi Children. Clin. Infect. Dis. 2019, 69, 786-794. [CrossRef]

100. Koopman, G.; Mooij, P.; Dekking, L.; Mortier, D.; Nieuwenhuis, I.G.; van Heteren, M.; Kuipers, H.; Remarque, E.J.; Radosevic, K.; Bogers, W.M. Correlation between Virus Replication and Antibody Responses in Macaques following Infection with Pandemic Influenza A Virus. J. Virol. 2016, 90, 1023-1033. [CrossRef]

101. Chen, M.I.; Lee, V.J.; Lim, W.Y.; Barr, I.G.; Lin, R.T.; Koh, G.C.; Yap, J.; Cui, L.; Cook, A.R.; Laurie, K.; et al. 2009 influenza A(H1N1) seroconversion rates and risk factors among distinct adult cohorts in Singapore. JAMA 2010, 303, 1383-1391. [CrossRef] [PubMed]

102. Wolfel, R.; Corman, V.M.; Guggemos, W.; Seilmaier, M.; Zange, S.; Muller, M.A.; Niemeyer, D.; Jones, T.C.; Vollmar, P.; Rothe, C.; et al. Virological assessment of hospitalized patients with COVID-2019. Nature 2020, 581, 465-469. [CrossRef]

103. Thompson, M.G.; Levine, M.Z.; Bino, S.; Hunt, D.R.; Al-Sanouri, T.M.; Simoes, E.A.F.; Porter, R.M.; Biggs, H.M.; Gresh, L.; Simaku, A.; et al. Underdetection of laboratory-confirmed influenza-associated hospital admissions among infants: A multicentre, prospective study. Lancet Child Adolesc. Health 2019, 3, 781-794. [CrossRef]

104. Rahil, Z.; Leylek, R.; Schurch, C.M.; Chen, H.; Bjornson-Hooper, Z.; Christensen, S.R.; Gherardini, P.F.; Bhate, S.S.; Spitzer, M.H.; Fragiadakis, G.K.; et al. Landscape of coordinated immune responses to H1N1 challenge in humans. J. Clin. Investig. 2020, 130, 5800-5816. [CrossRef] [PubMed]

105. Murphy, B.R.; Chanock, R.M.; Clements, M.L.; Anthony, W.C.; Sear, A.J.; Cisneros, L.A.; Rennels, M.B.; Miller, E.H.; Black, R.E.; Levine, M.M.; et al. Evaluation of A/Alaska/6/77 (H3N2) cold-adapted recombinant viruses derived from A/Ann Arbor/6/60 cold-adapted donor virus in adult seronegative volunteers. Infect. Immun. 1981, 32, 693-697. [CrossRef]

106. Shinjoh, M.; Sugaya, N.; Furuichi, M.; Araki, E.; Maeda, N.; Isshiki, K.; Ohnishi, T.; Nakamura, S.; Yamada, G.; Narabayashi, A.; et al. Effectiveness of inactivated influenza vaccine in children by vaccine dose, 2013-2018. Vaccine 2019, 37, 4047-4054. [CrossRef]

107. Goodwin, K.; Viboud, C.; Simonsen, L. Antibody response to influenza vaccination in the elderly: A quantitative review. Vaccine 2006, 24, 1159-1169. [CrossRef] [PubMed]

108. Chang, Y.T.; Guo, C.Y.; Tsai, M.S.; Cheng, Y.Y.; Lin, M.T.; Chen, C.H.; Shen, D.; Wang, J.R.; Sung, J.M. Poor immune response to a standard single dose non-adjuvanted vaccination against 2009 pandemic H1N1 influenza virus A in the adult and elder hemodialysis patients. Vaccine 2012, 30, 5009-5018. [CrossRef] [PubMed]

109. Skowronski, D.M.; Tweed, S.A.; De Serres, G. Rapid decline of influenza vaccine-induced antibody in the elderly: Is it real, or is it relevant? J. Infect. Dis. 2008, 197, 490-502. [CrossRef]

110. Crooke, S.N.; Ovsyannikova, I.G.; Poland, G.A.; Kennedy, R.B. Immunosenescence and human vaccine immune responses. Immun. Ageing 2019, 16, 25. [CrossRef]

111. Goronzy, J.J.; Weyand, C.M. Understanding immunosenescence to improve responses to vaccines. Nat. Immunol. 2013, 14, 428-436. [CrossRef] [PubMed]

112. Van Duin, D.; Allore, H.G.; Mohanty, S.; Ginter, S.; Newman, F.K.; Belshe, R.B.; Medzhitov, R.; Shaw, A.C. Prevaccine determination of the expression of costimulatory B7 molecules in activated monocytes predicts influenza vaccine responses in young and older adults. J. Infect. Dis. 2007, 195, 1590-1597. [CrossRef] [PubMed]

113. Khurana, S.; Frasca, D.; Blomberg, B.; Golding, H. AID activity in B cells strongly correlates with polyclonal antibody affinity maturation in-vivo following pandemic 2009-H1N1 vaccination in humans. PLoS Pathog. 2012, 8, e1002920. [CrossRef] [PubMed]

114. Goenka, R.; Scholz, J.L.; Naradikian, M.S.; Cancro, M.P. Memory B cells form in aged mice despite impaired affinity maturation and germinal center kinetics. Exp. Gerontol. 2014, 54, 109-115. [CrossRef] [PubMed]

115. Jiang, N.; He, J.; Weinstein, J.A.; Penland, L.; Sasaki, S.; He, X.S.; Dekker, C.L.; Zheng, N.Y.; Huang, M.; Sullivan, M.; et al. Lineage structure of the human antibody repertoire in response to influenza vaccination. Sci. Transl. Med. 2013, 5, 171ra19. [CrossRef]

116. De Bourcy, C.F.; Angel, C.J.; Vollmers, C.; Dekker, C.L.; Davis, M.M.; Quake, S.R. Phylogenetic analysis of the human antibody repertoire reveals quantitative signatures of immune senescence and aging. Proc. Natl. Acad. Sci. USA 2017, 114, 1105-1110. [CrossRef]

117. Najarro, K.; Nguyen, H.; Chen, G.; Xu, M.; Alcorta, S.; Yao, X.; Zukley, L.; Metter, E.J.; Truong, T.; Lin, Y.; et al. Telomere Length as an Indicator of the Robustness of B- and T-Cell Response to Influenza in Older Adults. J. Infect. Dis. 2015, 212, 1261-1269. [CrossRef]

118. Henry, C.; Zheng, N.Y.; Huang, M.; Cabanov, A.; Rojas, K.T.; Kaur, K.; Andrews, S.F.; Palm, A.E.; Chen, Y.Q.; Li, Y.; et al. Influenza Virus Vaccination Elicits Poorly Adapted B Cell Responses in Elderly Individuals. Cell Host Microbe 2019, 25, 357-366. [CrossRef]

119. Strandberg, T.E.; Pitkala, K.H. Frailty in elderly people. Lancet 2007, 369, 1328-1329. [CrossRef]

120. Yao, X.; Hamilton, R.G.; Weng, N.P.; Xue, Q.L.; Bream, J.H.; Li, H.; Tian, J.; Yeh, S.H.; Resnick, B.; Xu, X.; et al. Frailty is associated with impairment of vaccine-induced antibody response and increase in post-vaccination influenza infection in community-dwelling older adults. Vaccine 2011, 29, 5015-5021. [CrossRef] 
121. Andrew, M.K.; Shinde, V.; Ye, L.; Hatchette, T.; Haguinet, F.; Dos Santos, G.; McElhaney, J.E.; Ambrose, A.; Boivin, G.; Bowie, W.; et al. The Importance of Frailty in the Assessment of Influenza Vaccine Effectiveness Against Influenza-Related Hospitalization in Elderly People. J. Infect. Dis. 2017, 216, 405-414. [CrossRef] [PubMed]

122. Bauer, J.M.; De Castro, A.; Bosco, N.; Romagny, C.; Diekmann, R.; Benyacoub, J.; Vidal, K. Influenza vaccine response in community-dwelling German prefrail and frail individuals. Immun. Ageing 2017, 14, 17. [CrossRef]

123. Narang, V.; Lu, Y.; Tan, C.; Camous, X.F.N.; Nyunt, S.Z.; Carre, C.; Mok, E.W.H.; Wong, G.; Maurer-Stroh, S.; Abel, B.; et al. Influenza Vaccine-Induced Antibody Responses Are Not Impaired by Frailty in the Community-Dwelling Elderly With Natural Influenza Exposure. Front. Immunol. 2018, 9, 2465. [CrossRef] [PubMed]

124. Moehling, K.K.; Nowalk, M.P.; Lin, C.J.; Bertolet, M.; Ross, T.M.; Carter, C.E.; Susick, M.; Saul, S.G.; Kaynar, A.M.; Bromberger, J.T.; et al. The effect of frailty on HAI response to influenza vaccine among community-dwelling adults $\geq 50$ years of age. Hum. Vaccines Immunother. 2018, 14, 361-367. [CrossRef]

125. Loeb, N.; Andrew, M.K.; Loeb, M.; Kuchel, G.A.; Haynes, L.; McElhaney, J.E.; Verschoor, C.P. Frailty Is Associated With Increased Hemagglutination-Inhibition Titers in a 4-Year Randomized Trial Comparing Standard- and High-Dose Influenza Vaccination. Open Forum Infect. Dis. 2020, 7, ofaa148. [CrossRef]

126. Ng, T.W.Y.; Perera, R.; Fang, V.J.; Yau, E.M.; Peiris, J.S.M.; Tam, Y.H.; Cowling, B.J. The Effect of Influenza Vaccination History on Changes in Hemagglutination Inhibition Titers after Receipt of the 2015-2016 Influenza Vaccine in Older Adults in Hong Kong. J. Infect. Dis. 2020, 221, 33-41. [CrossRef] [PubMed]

127. McLean, H.Q.; King, J.P.; Talley, P.; Flannery, B.; Spencer, S.; Levine, M.Z.; Friedrich, T.C.; Belongia, E.A. Effect of Previous-Season Influenza Vaccination on Serologic Response in Children During 3 Seasons, 2013-2014 Through 2015-2016. J. Pediatric Infect. Dis. Soc. 2020, 9, 173-180. [CrossRef] [PubMed]

128. McLean, H.Q.; Caspard, H.; Griffin, M.R.; Gaglani, M.; Peters, T.R.; Poehling, K.A.; Ambrose, C.S.; Belongia, E.A. Association of Prior Vaccination With Influenza Vaccine Effectiveness in Children Receiving Live Attenuated or Inactivated Vaccine. JAMA Netw. Open 2018, 1, e183742. [CrossRef]

129. Fazekas de St, G.; Webster, R.G. Disquisitions of Original Antigenic Sin. I. Evidence in man. J. Exp. Med. 1966, 124, 331-345. [CrossRef]

130. Nachbagauer, R.; Choi, A.; Hirsh, A.; Margine, I.; Iida, S.; Barrera, A.; Ferres, M.; Albrecht, R.A.; Garcia-Sastre, A.; Bouvier, N.M.; et al. Defining the antibody cross-reactome directed against the influenza virus surface glycoproteins. Nat. Immunol. 2017, 18, 464-473. [CrossRef] [PubMed]

131. Henry, C.; Palm, A.E.; Krammer, F.; Wilson, P.C. From Original Antigenic Sin to the Universal Influenza Virus Vaccine. Trends Immunol. 2018, 39, 70-79. [CrossRef] [PubMed]

132. Fonville, J.M.; Wilks, S.H.; James, S.L.; Fox, A.; Ventresca, M.; Aban, M.; Xue, L.; Jones, T.C.; Le, N.M.H.; Pham, Q.T.; et al. Antibody landscapes after influenza virus infection or vaccination. Science 2014, 346, 996-1000. [CrossRef] [PubMed]

133. Hinojosa, M.; Shepard, S.S.; Chung, J.R.; King, J.P.; McLean, H.Q.; Flannery, B.; Belongia, E.A.; Levine, M.Z. Impact of Immune Priming, Vaccination and Infection on Influenza A(H3N2) Antibody Landscapes in Children. J. Infect. Dis. 2020. [CrossRef] [PubMed]

134. Nachbagauer, R.; Choi, A.; Izikson, R.; Cox, M.M.; Palese, P.; Krammer, F. Age Dependence and Isotype Specificity of Influenza Virus Hemagglutinin Stalk-Reactive Antibodies in Humans. mBio 2016, 7, e01996-15. [CrossRef]

135. Rajendran, M.; Nachbagauer, R.; Ermler, M.E.; Bunduc, P.; Amanat, F.; Izikson, R.; Cox, M.; Palese, P.; Eichelberger, M.; Krammer, F. Analysis of Anti-Influenza Virus Neuraminidase Antibodies in Children, Adults, and the Elderly by ELISA and Enzyme Inhibition: Evidence for Original Antigenic Sin. mBio 2017, 8. [CrossRef] [PubMed]

136. Meade, P.; Kuan, G.; Strohmeier, S.; Maier, H.E.; Amanat, F.; Balmaseda, A.; Ito, K.; Kirkpatrick, E.; Javier, A.; Gresh, L.; et al. Influenza Virus Infection Induces a Narrow Antibody Response in Children but a Broad Recall Response in Adults. mBio 2020, 11. [CrossRef] [PubMed]

137. Wong, S.S.; Waite, B.; Ralston, J.; Wood, T.; Reynolds, G.E.; Seeds, R.; Newbern, E.C.; Thompson, M.G.; Huang, Q.S.; Webby, R.J.; et al. Hemagglutinin and Neuraminidase Antibodies Are Induced in an Age- and Subtype-Dependent Manner after Influenza Virus Infection. J. Virol. 2020, 94. [CrossRef] [PubMed]

138. Carreno, J.M.; McDonald, J.U.; Hurst, T.; Rigsby, P.; Atkinson, E.; Charles, L.; Nachbagauer, R.; Behzadi, M.A.; Strohmeier, S.; Coughlan, L.; et al. Development and Assessment of a Pooled Serum as Candidate Standard to Measure Influenza A Virus Group 1 Hemagglutinin Stalk-Reactive Antibodies. Vaccines 2020, 8, 666. [CrossRef]

139. Eichelberger, M.C.; Couzens, L.; Gao, Y.; Levine, M.; Katz, J.; Wagner, R.; Thompson, C.I.; Hoschler, K.; Laurie, K.; Bai, T.; et al. Comparability of neuraminidase inhibition antibody titers measured by enzyme-linked lectin assay (ELLA) for the analysis of influenza vaccine immunogenicity. Vaccine 2016, 34, 458-465. [CrossRef] [PubMed]

140. Gabriel, G.; Arck, P.C. Sex, immunity and influenza. J. Infect. Dis. 2014, 209 (Suppl. 3), S93-S99. [CrossRef] [PubMed]

141. Morgan, R.; Klein, S.L. The intersection of sex and gender in the treatment of influenza. Curr. Opin. Virol. $2019,35,35-41$. [CrossRef] [PubMed]

142. Engler, R.J.; Nelson, M.R.; Klote, M.M.; VanRaden, M.J.; Huang, C.Y.; Cox, N.J.; Klimov, A.; Keitel, W.A.; Nichol, K.L.; Carr, W.W.; et al. Half- vs full-dose trivalent inactivated influenza vaccine (2004-2005): Age, dose, and sex effects on immune responses. Arch Intern. Med. 2008, 168, 2405-2414. [CrossRef] 
143. Falsey, A.R.; Treanor, J.J.; Tornieporth, N.; Capellan, J.; Gorse, G.J. Randomized, double-blind controlled phase 3 trial comparing the immunogenicity of high-dose and standard-dose influenza vaccine in adults 65 years of age and older. J. Infect. Dis. 2009, 200, 172-180. [CrossRef] [PubMed]

144. Kao, T.M.; Hsieh, S.M.; Kung, H.C.; Lee, Y.C.; Huang, K.C.; Huang, L.M.; Chang, F.Y.; Wang, N.C.; Liu, Y.C.; Lee, W.S.; et al. Immune response of single dose vaccination against 2009 pandemic influenza A (H1N1) in the Taiwanese elderly. Vaccine 2010, 28, 6159-6163. [CrossRef]

145. Chambers, C.; Skowronski, D.M.; Rose, C.; Serres, G.; Winter, A.L.; Dickinson, J.A.; Jassem, A.; Gubbay, J.B.; Fonseca, K.; Drews, S.J.; et al. Should Sex Be Considered an Effect Modifier in the Evaluation of Influenza Vaccine Effectiveness? Open Forum Infect. Dis. 2018, 5, ofy211. [CrossRef]

146. Furman, D.; Hejblum, B.P.; Simon, N.; Jojic, V.; Dekker, C.L.; Thiebaut, R.; Tibshirani, R.J.; Davis, M.M. Systems analysis of sex differences reveals an immunosuppressive role for testosterone in the response to influenza vaccination. Proc. Natl. Acad. Sci. USA 2014, 111, 869-874. [CrossRef] [PubMed]

147. Potluri, T.; Fink, A.L.; Sylvia, K.E.; Dhakal, S.; Vermillion, M.S.; Vom Steeg, L.; Deshpande, S.; Narasimhan, H.; Klein, S.L. Age-associated changes in the impact of sex steroids on influenza vaccine responses in males and females. NPJ Vaccines 2019, 4, 29. [CrossRef]

148. Wen, F.; Guo, J.; Li, Z.; Huang, S. Sex-specific patterns of gene expression following influenza vaccination. Sci. Rep. 2018, 8, 13517. [CrossRef] [PubMed]

149. Voigt, E.A.; Ovsyannikova, I.G.; Kennedy, R.B.; Grill, D.E.; Goergen, K.M.; Schaid, D.J.; Poland, G.A. Sex Differences in Older Adults' Immune Responses to Seasonal Influenza Vaccination. Front. Immunol. 2019, 10, 180. [CrossRef] [PubMed]

150. Klein, S.L.; Flanagan, K.L. Sex differences in immune responses. Nat. Rev. Immunol. 2016, 16, 626-638. [CrossRef] [PubMed]

151. Klein, S.L.; Jedlicka, A.; Pekosz, A. The Xs and Y of immune responses to viral vaccines. Lancet Infect. Dis. 2010, 10, 338-349. [CrossRef]

152. Nowak, J.; Pawlowski, B.; Borkowska, B.; Augustyniak, D.; Drulis-Kawa, Z. No evidence for the immunocompetence handicap hypothesis in male humans. Sci. Rep. 2018, 8, 7392. [CrossRef] [PubMed]

153. Vom Steeg, L.G.; Klein, S.L. Sex and sex steroids impact influenza pathogenesis across the life course. Semin. Immunopathol. 2019, 41, 189-194. [CrossRef]

154. Zivkovic, I.; Bufan, B.; Petrusic, V.; Minic, R.; Arsenovic-Ranin, N.; Petrovic, R.; Leposavic, G. Sexual diergism in antibody response to whole virus trivalent inactivated influenza vaccine in outbred mice. Vaccine 2015, 33, 5546-5552. [CrossRef]

155. Zivkovic, I.; Petrovic, R.; Arsenovic-Ranin, N.; Petrusic, V.; Minic, R.; Bufan, B.; Popovic, O.; Leposavic, G. Sex bias in mouse humoral immune response to influenza vaccine depends on the vaccine type. Biologicals 2018, 52, 18-24. [CrossRef] [PubMed]

156. Fink, A.L.; Engle, K.; Ursin, R.L.; Tang, W.Y.; Klein, S.L. Biological sex affects vaccine efficacy and protection against influenza in mice. Proc. Natl. Acad. Sci. USA 2018, 115, 12477-12482. [CrossRef] [PubMed]

157. Petrovic, R.; Bufan, B.; Arsenovic-Ranin, N.; Zivkovic, I.; Minic, R.; Radojevic, K.; Leposavic, G. Mouse strain and sex as determinants of immune response to trivalent influenza vaccine. Life Sci. 2018, 207, 117-126. [CrossRef] [PubMed]

158. Arsenovic-Ranin, N.; Petrovic, R.; Zivkovic, I.; Bufan, B.; Stoiljkovic, V.; Leposavic, G. Influence of aging on germinal centre reaction and antibody response to inactivated influenza virus antigens in mice: Sex-based differences. Biogerontology 2019, 20, 475-496. [CrossRef]

159. Bufan, B.; Arsenovic-Ranin, N.; Petrovic, R.; Zivkovic, I.; Stoiljkovic, V.; Leposavic, G. Strain specificities in influence of ageing on germinal centre reaction to inactivated influenza virus antigens in mice: Sex-based differences. Exp. Gerontol. 2020, $133,110857$. [CrossRef] [PubMed]

160. Khurana, S.; Verma, N.; Talaat, K.R.; Karron, R.A.; Golding, H. Immune response following H1N1pdm09 vaccination: Differences in antibody repertoire and avidity in young adults and elderly populations stratified by age and gender. J. Infect. Dis. 2012, 205, 610-620. [CrossRef] [PubMed]

161. Lorenzo, M.E.; Hodgson, A.; Robinson, D.P.; Kaplan, J.B.; Pekosz, A.; Klein, S.L. Antibody responses and cross protection against lethal influenza A viruses differ between the sexes in C57BL/ 6 mice. Vaccine 2011, 29, 9246-9255. [CrossRef]

162. Larcombe, A.N.; Foong, R.E.; Bozanich, E.M.; Berry, L.J.; Garratt, L.W.; Gualano, R.C.; Jones, J.E.; Dousha, L.F.; Zosky, G.R.; Sly, P.D. Sexual dimorphism in lung function responses to acute influenza A infection. Influenza Other Respir. Viruses 2011, 5, 334-342. [CrossRef] [PubMed]

163. Hoffmann, J.; Otte, A.; Thiele, S.; Lotter, H.; Shu, Y.; Gabriel, G. Sex differences in H7N9 influenza A virus pathogenesis. Vaccine 2015, 33, 6949-6954. [CrossRef] [PubMed]

164. Kay, A.W.; Bayless, N.L.; Fukuyama, J.; Aziz, N.; Dekker, C.L.; Mackey, S.; Swan, G.E.; Davis, M.M.; Blish, C.A. Pregnancy Does Not Attenuate the Antibody or Plasmablast Response to Inactivated Influenza Vaccine. J. Infect. Dis. 2015, 212, 861-870. [CrossRef]

165. Gounder, A.P.; Boon, A.C.M. Influenza Pathogenesis: The Effect of Host Factors on Severity of Disease. J. Immunol. 2019, 202, 341-350. [CrossRef] [PubMed]

166. Lei, N.; Li, Y.; Sun, Q.; Lu, J.; Zhou, J.; Li, Z.; Liu, L.; Guo, J.; Qin, K.; Wang, H.; et al. IFITM3 affects the level of antibody response after influenza vaccination. Emerg. Microbes Infect. 2020, 9, 976-987. [CrossRef]

167. Everitt, A.R.; Clare, S.; Pertel, T.; John, S.P.; Wash, R.S.; Smith, S.E.; Chin, C.R.; Feeley, E.M.; Sims, J.S.; Adams, D.J.; et al. IFITM3 restricts the morbidity and mortality associated with influenza. Nature 2012, 484, 519-523. [CrossRef] 
168. Zhang, Y.H.; Zhao, Y.; Li, N.; Peng, Y.C.; Giannoulatou, E.; Jin, R.H.; Yan, H.P.; Wu, H.; Liu, J.H.; Liu, N.; et al. Interferon-induced transmembrane protein-3 genetic variant rs12252-C is associated with severe influenza in Chinese individuals. Nat. Commun. 2013, 4, 1418. [CrossRef]

169. Kim, Y.C.; Jeong, B.H. No Correlation of the Disease Severity of Influenza A Virus Infection with the rs12252 Polymorphism of the Interferon-Induced Transmembrane Protein 3 Gene. Intervirology 2017, 60, 69-74. [CrossRef]

170. Randolph, A.G.; Yip, W.K.; Allen, E.K.; Rosenberger, C.M.; Agan, A.A.; Ash, S.A.; Zhang, Y.; Bhangale, T.R.; Finkelstein, D.; Cvijanovich, N.Z.; et al. Evaluation of IFITM3 rs12252 Association With Severe Pediatric Influenza Infection. J. Infect. Dis. 2017, 216, 14-21. [CrossRef]

171. Allen, E.K.; Randolph, A.G.; Bhangale, T.; Dogra, P.; Ohlson, M.; Oshansky, C.M.; Zamora, A.E.; Shannon, J.P.; Finkelstein, D.; Dressen, A.; et al. SNP-mediated disruption of CTCF binding at the IFITM3 promoter is associated with risk of severe influenza in humans. Nat. Med. 2017, 23, 975-983. [CrossRef]

172. Stertz, S.; Hale, B.G. Interferon system deficiencies exacerbating severe pandemic virus infections. Trends Microbiol. 2021. [CrossRef] [PubMed]

173. Hyde, T.B.; Schmid, D.S.; Cannon, M.J. Cytomegalovirus seroconversion rates and risk factors: Implications for congenital CMV. Rev. Med. Virol. 2010, 20, 311-326. [CrossRef] [PubMed]

174. Cheung, A.K.; Gottlieb, D.J.; Plachter, B.; Pepperl-Klindworth, S.; Avdic, S.; Cunningham, A.L.; Abendroth, A.; Slobedman, B. The role of the human cytomegalovirus UL111A gene in down-regulating CD4 ${ }^{+}$T-cell recognition of latently infected cells: Implications for virus elimination during latency. Blood 2009, 114, 4128-4137. [CrossRef]

175. Poole, E.; Neves, T.C.; Oliveira, M.T.; Sinclair, J.; da Silva, M.C.C. Human Cytomegalovirus Interleukin 10 Homologs: Facing the Immune System. Front. Cell. Infect. Microbiol. 2020, 10, 245. [CrossRef] [PubMed]

176. Kallemeijn, M.J.; Boots, A.M.H.; van der Klift, M.Y.; Brouwer, E.; Abdulahad, W.H.; Verhaar, J.A.N.; van Dongen, J.J.M.; Langerak, A.W. Ageing and latent CMV infection impact on maturation, differentiation and exhaustion profiles of T-cell receptor gammadelta T-cells. Sci. Rep. 2017, 7, 5509. [CrossRef]

177. Stone, S.F.; Price, P.; Tay-Kearney, M.L.; French, M.A. Cytomegalovirus (CMV) retinitis immune restoration disease occurs during highly active antiretroviral therapy-induced restoration of CMV-specific immune responses within a predominant Th2 cytokine environment. J. Infect. Dis. 2002, 185, 1813-1817. [CrossRef] [PubMed]

178. Cervera, C.; Filella, X.; Linares, L.; Pineda, M.; Esteva, C.; Anton, A.; Marcos, M.A.; Cofan, F.; Navasa, M.; Perez-Villa, F.; et al. TH1/TH2 cytokine release pattern during in vivo cytomegalovirus disease in solid organ transplantation. Transplant. Proc. 2007, 39, 2233-2235. [CrossRef]

179. Essa, S.; Pacsa, A.; Raghupathy, R.; Said, T.; Nampoory, M.R.; Johny, K.V.; Al-Nakib, W. Low levels of Th1-type cytokines and increased levels of Th2-type cytokines in kidney transplant recipients with active cytomegalovirus infection. Transplant. Proc. 2009, 41, 1643-1647. [CrossRef]

180. Frasca, D.; Diaz, A.; Romero, M.; Landin, A.M.; Blomberg, B.B. Cytomegalovirus (CMV) seropositivity decreases B cell responses to the influenza vaccine. Vaccine 2015, 33, 1433-1439. [CrossRef]

181. Frasca, D.; Diaz, A.; Romero, M.; Landin, A.M.; Phillips, M.; Lechner, S.C.; Ryan, J.G.; Blomberg, B.B. Intrinsic defects in B cell response to seasonal influenza vaccination in elderly humans. Vaccine 2010, 28, 8077-8084. [CrossRef]

182. Frasca, D.; Diaz, A.; Romero, M.; Mendez, N.V.; Landin, A.M.; Ryan, J.G.; Blomberg, B.B. Young and elderly patients with type 2 diabetes have optimal B cell responses to the seasonal influenza vaccine. Vaccine 2013, 31, 3603-3610. [CrossRef]

183. Frasca, D.; Diaz, A.; Romero, M.; Phillips, M.; Mendez, N.V.; Landin, A.M.; Blomberg, B.B. Unique biomarkers for B-cell function predict the serum response to pandemic H1N1 influenza vaccine. Int. Immunol. 2012, 24, 175-182. [CrossRef]

184. Litjens, N.H.; de Wit, E.A.; Betjes, M.G. Differential effects of age, cytomegalovirus-seropositivity and end-stage renal disease (ESRD) on circulating T lymphocyte subsets. Immun. Ageing 2011, 8, 2. [CrossRef]

185. Derhovanessian, E.; Maier, A.B.; Hahnel, K.; Beck, R.; de Craen, A.J.M.; Slagboom, E.P.; Westendorp, R.G.J.; Pawelec, G. Infection with cytomegalovirus but not herpes simplex virus induces the accumulation of late-differentiated CD4 ${ }^{+}$and $\mathrm{CD} 8^{+} \mathrm{T}$-cells in humans. J. Gen. Virol. 2011, 92 Pt 12, 2746-2756. [CrossRef]

186. Wald, A.; Selke, S.; Magaret, A.; Boeckh, M. Impact of human cytomegalovirus (CMV) infection on immune response to pandemic 2009 H1N1 influenza vaccine in healthy adults. J. Med. Virol. 2013, 85, 1557-1560. [CrossRef]

187. Wertheimer, A.M.; Bennett, M.S.; Park, B.; Uhrlaub, J.L.; Martinez, C.; Pulko, V.; Currier, N.L.; Nikolich-Zugich, D.; Kaye, J.; Nikolich-Zugich, J. Aging and cytomegalovirus infection differentially and jointly affect distinct circulating $\mathrm{T}$ cell subsets in humans. J. Immunol. 2014, 192, 2143-2155. [CrossRef]

188. Hadrup, S.R.; Strindhall, J.; Kollgaard, T.; Seremet, T.; Johansson, B.; Pawelec, G.; thor Straten, P.; Wikby, A. Longitudinal studies of clonally expanded CD8 T cells reveal a repertoire shrinkage predicting mortality and an increased number of dysfunctional cytomegalovirus-specific T cells in the very elderly. J. Immunol. 2006, 176, 2645-2653. [CrossRef]

189. Lachmann, R.; Bajwa, M.; Vita, S.; Smith, H.; Cheek, E.; Akbar, A.; Kern, F. Polyfunctional T cells accumulate in large human cytomegalovirus-specific T cell responses. J. Virol. 2012, 86, 1001-1009. [CrossRef]

190. Saurwein-Teissl, M.; Lung, T.L.; Marx, F.; Gschosser, C.; Asch, E.; Blasko, I.; Parson, W.; Bock, G.; Schonitzer, D.; Trannoy, E.; et al. Lack of antibody production following immunization in old age: Association with CD8(+)CD28(-) T cell clonal expansions and an imbalance in the production of Th1 and Th2 cytokines. J. Immunol. 2002, 168, 5893-5899. [CrossRef] 
191. Goronzy, J.J.; Fulbright, J.W.; Crowson, C.S.; Poland, G.A.; O'Fallon, W.M.; Weyand, C.M. Value of immunological markers in predicting responsiveness to influenza vaccination in elderly individuals. J. Virol. 2001, 75, 12182-12187. [CrossRef] [PubMed]

192. Xie, D.; McElhaney, J.E. Lower GrB+ CD62 $\mathrm{L}^{\text {high }} \mathrm{CD} 8 \mathrm{~T}_{\mathrm{CM}}$ effector lymphocyte response to influenza virus in older adults is associated with increased CD28 ${ }^{\text {null }}$ CD8 T lymphocytes. Mech. Ageing Dev. 2007, 128, 392-400. [CrossRef]

193. Derhovanessian, E.; Theeten, H.; Hahnel, K.; Van Damme, P.; Cools, N.; Pawelec, G. Cytomegalovirus-associated accumulation of late-differentiated CD4 T-cells correlates with poor humoral response to influenza vaccination. Vaccine 2013, 31, 685-690. [CrossRef] [PubMed]

194. Derhovanessian, E.; Maier, A.B.; Hahnel, K.; McElhaney, J.E.; Slagboom, E.P.; Pawelec, G. Latent infection with cytomegalovirus is associated with poor memory CD4 responses to influenza A core proteins in the elderly. J. Immunol. 2014, 193, 3624-3631. [CrossRef] [PubMed]

195. Trzonkowski, P.; Mysliwska, J.; Szmit, E.; Wieckiewicz, J.; Lukaszuk, K.; Brydak, L.B.; Machala, M.; Mysliwski, A. Association between cytomegalovirus infection, enhanced proinflammatory response and low level of anti-hemagglutinins during the anti-influenza vaccination-An impact of immunosenescence. Vaccine 2003, 21, 3826-3836. [CrossRef]

196. Pawelec, G.; McElhaney, J.E.; Aiello, A.E.; Derhovanessian, E. The impact of CMV infection on survival in older humans. Curr. Opin. Immunol. 2012, 24, 507-511. [CrossRef]

197. Solana, R.; Tarazona, R.; Aiello, A.E.; Akbar, A.N.; Appay, V.; Beswick, M.; Bosch, J.A.; Campos, C.; Cantisan, S.; Cicin-Sain, L.; et al. CMV and Immunosenescence: From basics to clinics. Immun. Ageing 2012, 9, 23. [CrossRef] [PubMed]

198. Den Elzen, W.P.; Vossen, A.C.; Cools, H.J.; Westendorp, R.G.; Kroes, A.C.; Gussekloo, J. Cytomegalovirus infection and responsiveness to influenza vaccination in elderly residents of long-term care facilities. Vaccine 2011, 29, 4869-4874. [CrossRef]

199. Furman, D.; Jojic, V.; Sharma, S.; Shen-Orr, S.S.; Angel, C.J.; Onengut-Gumuscu, S.; Kidd, B.A.; Maecker, H.T.; Concannon, P.; Dekker, C.L.; et al. Cytomegalovirus infection enhances the immune response to influenza. Sci. Transl. Med. 2015, 7, 281 ra43. [CrossRef]

200. Cook, C.H.; Trgovcich, J. Cytomegalovirus reactivation in critically ill immunocompetent hosts: A decade of progress and remaining challenges. Antivir. Res. 2011, 90, 151-159. [CrossRef]

201. Ke, C.; Mok, C.K.P.; Zhu, W.; Zhou, H.; He, J.; Guan, W.; Wu, J.; Song, W.; Wang, D.; Liu, J.; et al. Human Infection with Highly Pathogenic Avian Influenza A(H7N9) Virus, China. Emerg. Infect. Dis. 2017, 23, 1332-1340. [CrossRef] [PubMed]

202. Yang, Z.F.; Mok, C.K.; Liu, X.Q.; Li, X.B.; He, J.F.; Guan, W.D.; Xu, Y.H.; Pan, W.Q.; Chen, L.Y.; Lin, Y.P.; et al. Clinical, virological and immunological features from patients infected with re-emergent avian-origin human H7N9 influenza disease of varying severity in Guangdong province. PLoS ONE 2015, 10, e0117846. [CrossRef]

203. Van den Berg, S.P.H.; Warmink, K.; Borghans, J.A.M.; Knol, M.J.; van Baarle, D. Effect of latent cytomegalovirus infection on the antibody response to influenza vaccination: A systematic review and meta-analysis. Med. Microbiol. Immunol. 2019, 208, 305-321. [CrossRef] [PubMed]

204. George, V.K.; Pallikkuth, S.; Parmigiani, A.; Alcaide, M.; Fischl, M.; Arheart, K.L.; Pahwa, S. HIV infection Worsens Age-Associated Defects in Antibody Responses to Influenza Vaccine. J. Infect. Dis. 2015, 211, 1959-1968. [CrossRef]

205. Amendola, A.; Boschini, A.; Colzani, D.; Anselmi, G.; Oltolina, A.; Zucconi, R.; Begnini, M.; Besana, S.; Tanzi, E.; Zanetti, A.R. Influenza vaccination of HIV-1-positive and HIV-1-negative former intravenous drug users. J. Med. Virol. 2001, 65, 644-648. [CrossRef] [PubMed]

206. Kroon, F.P.; Rimmelzwaan, G.F.; Roos, M.T.; Osterhaus, A.D.; Hamann, D.; Miedema, F.; van Dissel, J.T. Restored humoral immune response to influenza vaccination in HIV-infected adults treated with highly active antiretroviral therapy. AIDS 1998, 12, F217-F223. [CrossRef] [PubMed]

207. Staprans, S.I.; Hamilton, B.L.; Follansbee, S.E.; Elbeik, T.; Barbosa, P.; Grant, R.M.; Feinberg, M.B. Activation of virus replication after vaccination of HIV-1-infected individuals. J. Exp. Med. 1995, 182, 1727-1737. [CrossRef]

208. Durando, P.; Fenoglio, D.; Boschini, A.; Ansaldi, F.; Icardi, G.; Sticchi, L.; Renzoni, A.; Fabbri, P.; Ferrera, A.; Parodi, A.; et al. Safety and immunogenicity of two influenza virus subunit vaccines, with or without MF59 adjuvant, administered to human immunodeficiency virus type 1-seropositive and -seronegative adults. Clin. Vaccine Immunol. 2008, 15, 253-259. [CrossRef] [PubMed]

209. Zanetti, A.R.; Amendola, A.; Besana, S.; Boschini, A.; Tanzi, E. Safety and immunogenicity of influenza vaccination in individuals infected with HIV. Vaccine 2002, 20 (Suppl. 5), B29-B32. [CrossRef]

210. Evison, J.; Farese, S.; Seitz, M.; Uehlinger, D.E.; Furrer, H.; Muhlemann, K. Randomized, double-blind comparative trial of subunit and virosomal influenza vaccines for immunocompromised patients. Clin. Infect. Dis. 2009, 48, 1402-1412. [CrossRef]

211. Fuller, J.D.; Craven, D.E.; Steger, K.A.; Cox, N.; Heeren, T.C.; Chernoff, D. Influenza vaccination of human immunodeficiency virus (HIV)-infected adults: Impact on plasma levels of HIV type 1 RNA and determinants of antibody response. Clin. Infect. Dis. 1999, 28, 541-547. [CrossRef] [PubMed]

212. Trombetta, C.M.; Ulivieri, C.; Cox, R.J.; Remarque, E.J.; Centi, C.; Perini, D.; Piccini, G.; Rossi, S.; Marchi, S.; Montomoli, E. Impact of erythrocyte species on assays for influenza serology. J. Prev. Med. Hyg. 2018, 59, E1-E7. [CrossRef] [PubMed]

213. Kayali, G.; Setterquist, S.F.; Capuano, A.W.; Myers, K.P.; Gill, J.S.; Gray, G.C. Testing human sera for antibodies against avian influenza viruses: Horse RBC hemagglutination inhibition vs. microneutralization assays. J. Clin. Virol. 2008, 43, 73-78. [CrossRef] 
214. Jia, N.; Wang, S.X.; Liu, Y.X.; Zhang, P.H.; Zuo, S.Q.; Lin, Z.; Dang, R.L.; Ma, Y.H.; Zhang, C.; Zhang, L.; et al. Increased sensitivity for detecting avian influenza-specific antibodies by a modified hemagglutination inhibition assay using horse erythrocytes. $J$. Virol. Methods 2008, 153, 43-48. [CrossRef] [PubMed]

215. World Health Organization. Manual for the Laboratory Diagnosis and Virological Surveillance of Influenza; WHO Global Influenza Surveillance Network; World Health Organization: Geneva, Switzerland, 2011.

216. Allen, J.D.; Ross, T.M. H3N2 influenza viruses in humans: Viral mechanisms, evolution, and evaluation. Hum. Vaccines Immunother. 2018, 14, 1840-1847. [CrossRef]

217. Trombetta, C.M.; Remarque, E.J.; Mortier, D.; Montomoli, E. Comparison of hemagglutination inhibition, single radial hemolysis, virus neutralization assays, and ELISA to detect antibody levels against seasonal influenza viruses. Influenza Other Respir. Viruses 2018, 12, 675-686. [CrossRef] [PubMed]

218. Carnell, G.W.; Trombetta, C.M.; Ferrara, F.; Montomoli, E.; Temperton, N.J. Correlation of Influenza B Haemagglutination Inhibiton, Single-Radial Haemolysis and Pseudotype-Based Microneutralisation Assays for Immunogenicity Testing of Seasonal Vaccines. Vaccines 2021, 9, 100. [CrossRef] [PubMed]

219. Kendal, A.P.; Cate, T.R. Increased sensitivity and reduced specificity of hemagglutination inhibition tests with ether-treated influenza B/Singapore/222/79. J. Clin. Microbiol. 1983, 18, 930-934. [CrossRef]

220. Levine, M.Z.; Martin, E.T.; Petrie, J.G.; Lauring, A.S.; Holiday, C.; Jefferson, S.; Fitzsimmons, W.J.; Johnson, E.; Ferdinands, J.M.; Monto, A.S. Antibodies Against Egg- and Cell-Grown Influenza A(H3N2) Viruses in Adults Hospitalized During the 2017-2018 Influenza Season. J. Infect. Dis. 2019, 219, 1904-1912. [CrossRef] [PubMed]

221. Parker, L.; Wharton, S.A.; Martin, S.R.; Cross, K.; Lin, Y.; Liu, Y.; Feizi, T.; Daniels, R.S.; McCauley, J.W. Effects of egg-adaptation on receptor-binding and antigenic properties of recent influenza A (H3N2) vaccine viruses. J. Gen. Virol. 2016, 97, 1333-1344. [CrossRef] [PubMed]

222. Liu, F.; Gross, F.L.; Jefferson, S.N.; Holiday, C.; Bai, Y.; Wang, L.; Zhou, B.; Levine, M.Z. Age-specific effects of vaccine egg adaptation and immune priming on $\mathrm{A}(\mathrm{H} 3 \mathrm{~N} 2)$ antibody responses following influenza vaccination. J. Clin. Investig. 2021, 131. [CrossRef]

223. Huang, Q.S.; Bandaranayake, D.; Wood, T.; Newbern, E.C.; Seeds, R.; Ralston, J.; Waite, B.; Bissielo, A.; Prasad, N.; Todd, A.; et al. Risk Factors and Attack Rates of Seasonal Influenza Infection: Results of the Southern Hemisphere Influenza and Vaccine Effectiveness Research and Surveillance (SHIVERS) Seroepidemiologic Cohort Study. J. Infect. Dis. 2019, 219, 347-357. [CrossRef] [PubMed]

224. Lambré, C.R.; Terzidis, H.; Greffard, A.; Webster, R.G. Measurement of anti-influenza neuraminidase antibody using a peroxidaselinked lectin and microtitre plates coated with natural substrates. J. Immunol. Methods 1990, 135, 49-57. [CrossRef]

225. Webster, R.G.; Laver, W.G. Preparation and properties of antibody directed specifically against the neuraminidase of influenza virus. J. Immunol. 1967, 99, 49-55. [PubMed]

226. Couzens, L.; Gao, J.; Westgeest, K.; Sandbulte, M.; Lugovtsev, V.; Fouchier, R.; Eichelberger, M. An optimized enzyme-linked lectin assay to measure influenza A virus neuraminidase inhibition antibody titers in human sera. J. Virol. Methods 2014, 210, 7-14. [CrossRef] [PubMed]

227. Leang, S.K.; Hurt, A.C. Fluorescence-based Neuraminidase Inhibition Assay to Assess the Susceptibility of Influenza Viruses to The Neuraminidase Inhibitor Class of Antivirals. J. Vis. Exp. 2017. [CrossRef] [PubMed]

228. Buxton, R.C.; Edwards, B.; Juo, R.R.; Voyta, J.C.; Tisdale, M.; Bethell, R.C. Development of a sensitive chemiluminescent neuraminidase assay for the determination of influenza virus susceptibility to zanamivir. Anal. Biochem. 2000, 280, 291-300. [CrossRef] [PubMed]

229. Carnell, G.W.; Ferrara, F.; Grehan, K.; Thompson, C.P.; Temperton, N.J. Pseudotype-based neutralization assays for influenza: A systematic analysis. Front. Immunol. 2015, 6, 161. [CrossRef] [PubMed]

230. Ferrara, F.; Del Rosario, J.M.M.; da Costa, K.A.S.; Kinsley, R.; Scott, S.; Fereidouni, S.; Thompson, C.; Kellam, P.; Gilbert, S.; Carnell, G.; et al. Development of Lentiviral Vectors Pseudotyped With Influenza B Hemagglutinins: Application in Vaccine Immunogenicity, mAb Potency, and Sero-Surveillance Studies. Front. Immunol. 2021, 12, 661379. [CrossRef] [PubMed]

231. Chen, M.I.; Barr, I.G.; Koh, G.C.; Lee, V.J.; Lee, C.P.; Shaw, R.; Lin, C.; Yap, J.; Cook, A.R.; Tan, B.H.; et al. Serological response in RT-PCR confirmed H1N1-2009 influenza a by hemagglutination inhibition and virus neutralization assays: An observational study. PLoS ONE 2010, 5, e12474. [CrossRef] [PubMed]

232. Morrison, B.J.; Martin, N.J.; Rehman, T.; Ewing, D.; Dewar, R.L.; Metcalf, J.; Sun, P.; Beigel, J.; Luke, T.C.; Raviprakash, K. Influence of sample collection tube method, anticoagulant-containing plasma versus serum, on influenza virus hemagglutination inhibition titer and microneutralization titer serological assays. BMC Health Serv. Res. 2018, 18, 651. [CrossRef] [PubMed]

233. Defang, G.N.; Martin, N.J.; Burgess, T.H.; Millar, E.V.; Pecenka, L.A.; Danko, J.R.; Arnold, J.C.; Kochel, T.J.; Luke, T.C. Comparative analysis of hemagglutination inhibition titers generated using temporally matched serum and plasma samples. PLoS ONE 2012, 7, e48229. [CrossRef] [PubMed]

234. Ananthanarayan, R.; Paniker, C.K. Non-specific inhibitors of influenza viruses in normal sera. Bull. World Health Organ. 1960, 22, 409-419. [PubMed]

235. Katz, J.M.; Hancock, K.; Xu, X. Serologic assays for influenza surveillance, diagnosis and vaccine evaluation. Expert Rev. Anti Infect. Ther. 2011, 9, 669-683. [CrossRef] [PubMed] 